
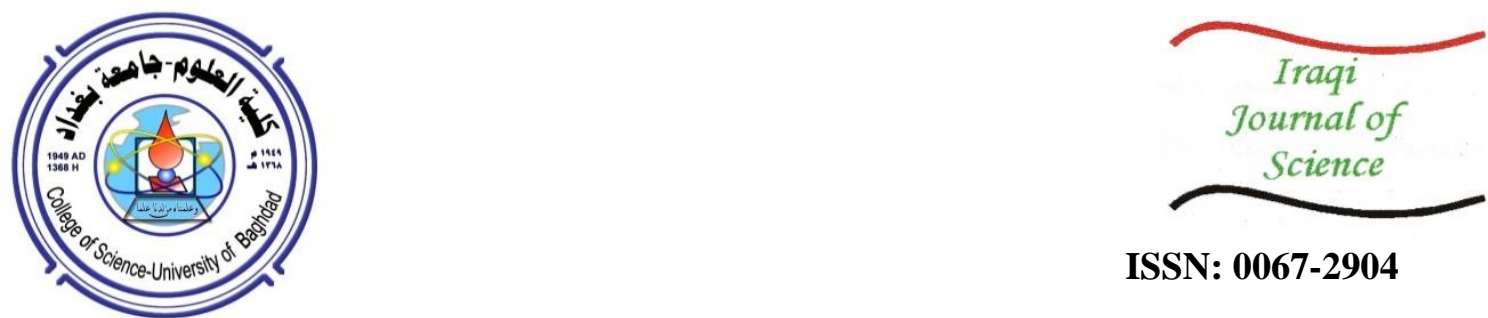

ISSN: 0067-2904

\title{
Ammonites and Foraminifera of Shiranish Formation (Late Campanian- Maastrichtian) from Sulaimaniya and Erbil Governorates, Northern Iraq
}

\author{
Anhar I. Kamil ${ }^{1 *}$, Salam Al-Dulaimi ${ }^{1}$, Kamal Haji Karim ${ }^{2}$ \\ ${ }^{I}$ Department of Geology, College of Science, Baghdad University. Baghdad, Iraq. \\ ${ }^{2}$ Department of Geology, College of Science, Sulaimaniya University. Sulaimaniya, Iraq.
}

Received: 15/10/2020

Accepted: 15/2/2021

\begin{abstract}
This study deals with the biostratigraphy of Shiranish Formation (Late Cretaceous), depending on the Ammonite and associated Foraminifera in four outcrop sections, three of which are located in Al-Sulaimaniya governorate (Dokan, Esewa and Kanny dirka sections) and one in Erbil governorate, northern Iraq (Hijran section). Fourteen species of Ammonite belonging to fourteen genera were determined, which are: Dsemoceratidae, Gaudryceras, Gunnarites, Hoplitoplacenticeras, Kitchinites, Kossmaticeratinae, Neancyloceras, Neokossmaticeras, Nostoceras, Paratexanites, Partschiceras, Phylloceras, Pseudophyllites and Yubariceras. Also, thirty- five species of Foraminifera belonging to thirteen genera were determined, which are: Cibicides, Cymopolia, Eggellina, Elphidium, Globigerinelloides, Globotruncana, Hedbergella, Heterohelix, Marginulina, Miliolid, Neobulimmina, Nodosaria and Textularia. Seven range zones were determined, three of which are of Ammonite, which are: Desmophyllites larteti (Seunes, 1892), Nostoceras (Nostoceras) hyatti and Pseudophyllites teres (Van Hoepen, 1920), whereas the others are of Foraminifera species, which are: Glt. gagnebini Tilev, Glt. tricarinata lapparenti Brotzen, Glt. tricarinata tricarinata (Querean) and Glt. Stuartiformis Dalbiez. According to these findings, the age of Shiranish Formation was determined as the Late Campanian- Maastrichtian.
\end{abstract}

Keywords: Biostratigraphy, Late Cretaceous, Shiranish Formation, Ammonite, Foraminifera, Northern Iraq.

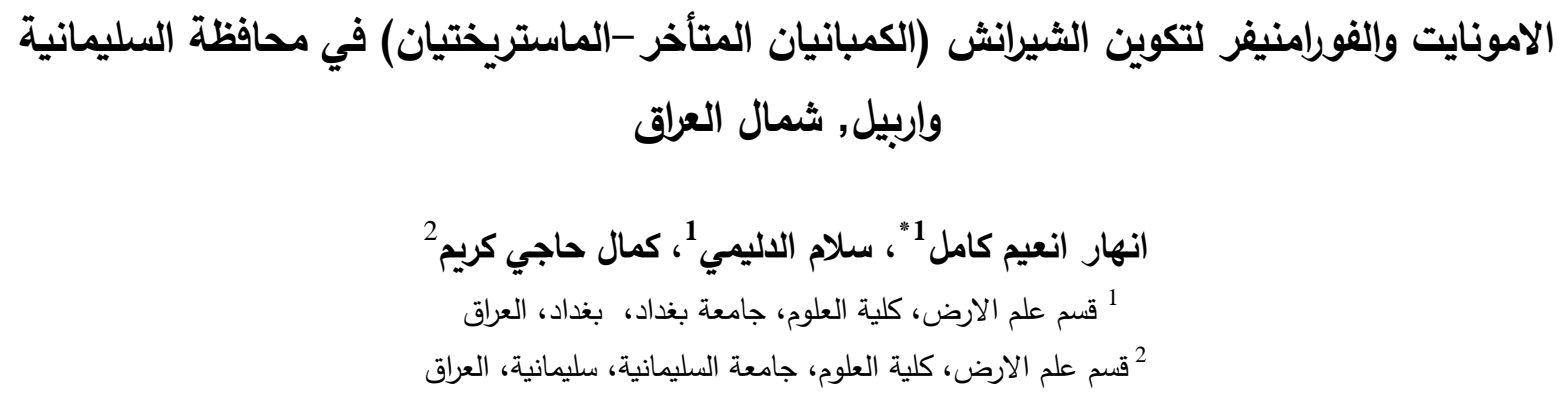

تتاولت هذه الدراسة الطباقية الحياتية لتكوين الثيرانش (الطباشيري الاعلى) أعتمادا على الامونايت والفورامنفيرا المصاحبة لها في اربع مقاطع سطحية,ثلاث منها في محافظة السليمانية وهي مقطع دوكان ومقطع كاني دركه ومقطع ايسوه ومقطع واحد في محافظة اربيل وهو مقطع هجران.

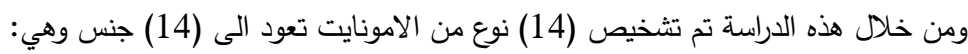

*Email: anhaarnaeem@gmail.com 
Dsemoceratidae, Gaudryceras, Gunnarites, Hoplitoplacenticeras, Kitchinites, Kossmaticeratinae, Neancyloceras, Neokossmaticeras, Nostoceras, Paratexanites, Partschiceras, Phylloceras, Pseudophyllites and Yubariceras.

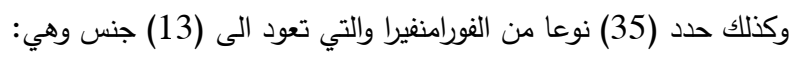

Cibicides, Cymopolia, Eggellina, Elphidium, Globigerinelloides, Globotruncana, Hedbergella, Heterohelix, Marginulina, Miliolid, Neobulimmina, Nodosaria and Textularia.

$$
\text { واعتمادا على تلك المتحجرات تم تحديد سبعة انطقة مدى حياتية, ثلاثة منها للامونايت وهي: }
$$

Desmophyllites larteti (Seunes, 1892), Nostoceras (Nostoceras) hyatti and

Pseudophyllites teres (Van Hoepen, 1920).

$$
\text { واربعة انطقة للفورامنفيرا وهي: }
$$

Glt. gagnebini Tilev, Glt. tricarinata lapparenti Brotzen, Glt. tricarinata tricarinata

(Querean) and G/t. Stuartiformis Dalbiez.

اما عمر التكوين فقد حدد بالكمباني المتأخر - الماسترختي اعتمادا على تلك الانطقة المثبتة محليا واقليميا.

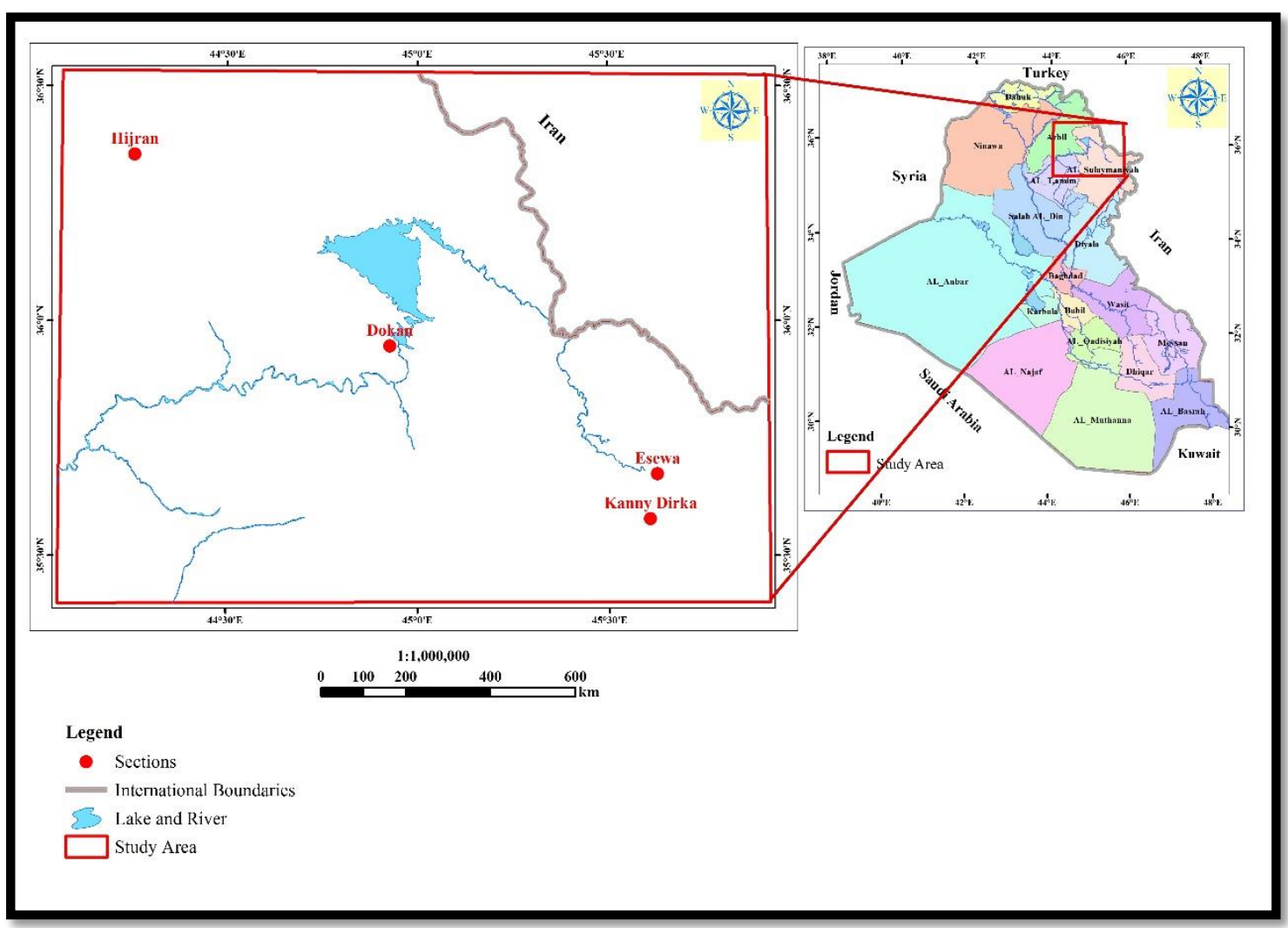

Figure 1-Location map of the study area

\section{Introduction}

Starting from earlier studies, Ammonites have been considered as prime biostratigraphic indicators in marine sediments [1-6]. The group generally possesses many of the characteristics of the ideal index fossil: wide, rapidly attained geographic distribution, high degree of facies independence, rapid evolutionary rates, and high preservation potential. Ammonites are conspicuous and commonly determinable even when fragmentary. These factors allow the recognition of fine biostratigraphic subdivisions that are correlatable over long distances [7]. 
As for planktonic Foraminifera, their use as guide fossils is generally accepted today. The Planktonic Foraminifera, being of practical use in biostratigraphy, first occurred during the Early Cretaceous. They have continued to distribute on a worldwide scale, and in a rapid succession of species, to the recent time [8].

Comprehensive studies dealing with the Late Cretaceous Ammonite- Foraminifera association within Shiranish Formation are limited. However, the present study of Shiranish Formation was conducted at four selected geological sections, which are Dokan, Hijran, Esewa and Kanny dirka (Figure 1). The current study aims to determine the biostratigraphy of the formation depending on the Ammonite fossils with Foraminifera associations.

\section{Results and Discussion}

According to the fossil associations of the Ammonites and Foraminifera, seven biozones were determined; three are related to the Ammonites and the other four are related to the planktonic Foraminifera. The following is a description of the recorded fossils in each section.

\section{Biostratigraphy of Dokan Section}

Various macrofauna were identified in the sediments of Shiranish Formation at the Dokan section (Figure 2). These include the following Ammonite species:

Desmophyllites larteti (Seunes, 1892) (Pl.1, Figures 3, 4), Gaudryceras denseplicatum (Jimbo, 1894) (Pl.1, Figures 1, 2), Gunnarites Kilian \& Reboul, 1909 (Pl.3, Figures 5, 6), Hoplitoplacenticeras (Hoplitoplacenticeras) Preyi sp. (Pl.5, Figures5,6), Kitchinites Kennedy \& Summesberger, 1999 (P1.2, Figures1,2), Kossmaticeratinae gen. et sp. nov. (P1.3, Figures 2, 3, 4), Neancyloceras bipunctatum (Schluter, 1872) (Pl.2, Figures 3, 4), Nostoceras (Nostoceras) hyatti (Pl.4, Figures 1, 2, 3), Phylloceras Kennedy \& Summesberger, 1999 (Pl.1, Figures 5, 6) and Pseudophyllites teres (Van Hoepen, 1920) (Pl.4, Figures 4, 5, 6).

The identified macrofauna also included the following Foraminifera:

Bucherina sandidgei Bronnimann and Brown. (Pl.8, Figure 2), Eggerellina gibbosa Marie (Pl.6, Figure 4), Glt. falsocalcarata Kerdany and Abdelsalam (P1.6, Figure 1), Glt. concavata cyrenaica Barr(Pl.7, Figure 6), Glt. gagnebini Tilev (Pl.7, Figure 2), Glt. marginata (Ruess) (Pl.7, Figure 4), Glt. conica White (Pl.8, Figure 5), Glt. stuartiformis Dalbiez (P1.8, Figure 6), Glt. tricarinata lapparenti Brotzen (Pl.7, Figure 5), Glt. tricarinata tricarinata (Quereau) (Pl.7, Figure 3), Globigerinelloides multispina (Lalicker) (Pl.6, Figures 2\&5), Globigerinelloides bollii Passagno (P1.8, Figures 3\&4 and Pl.13, Figure 6), Hedbergella sp. (Pl.6, Figure 6), Heterohelix sp. (Pl.6, Figure 3) and Textularia sp. (Pl.6, Figure 1). Other microfossils were also identified, such as Ostracoda shells (P1.8, Figure 1). 


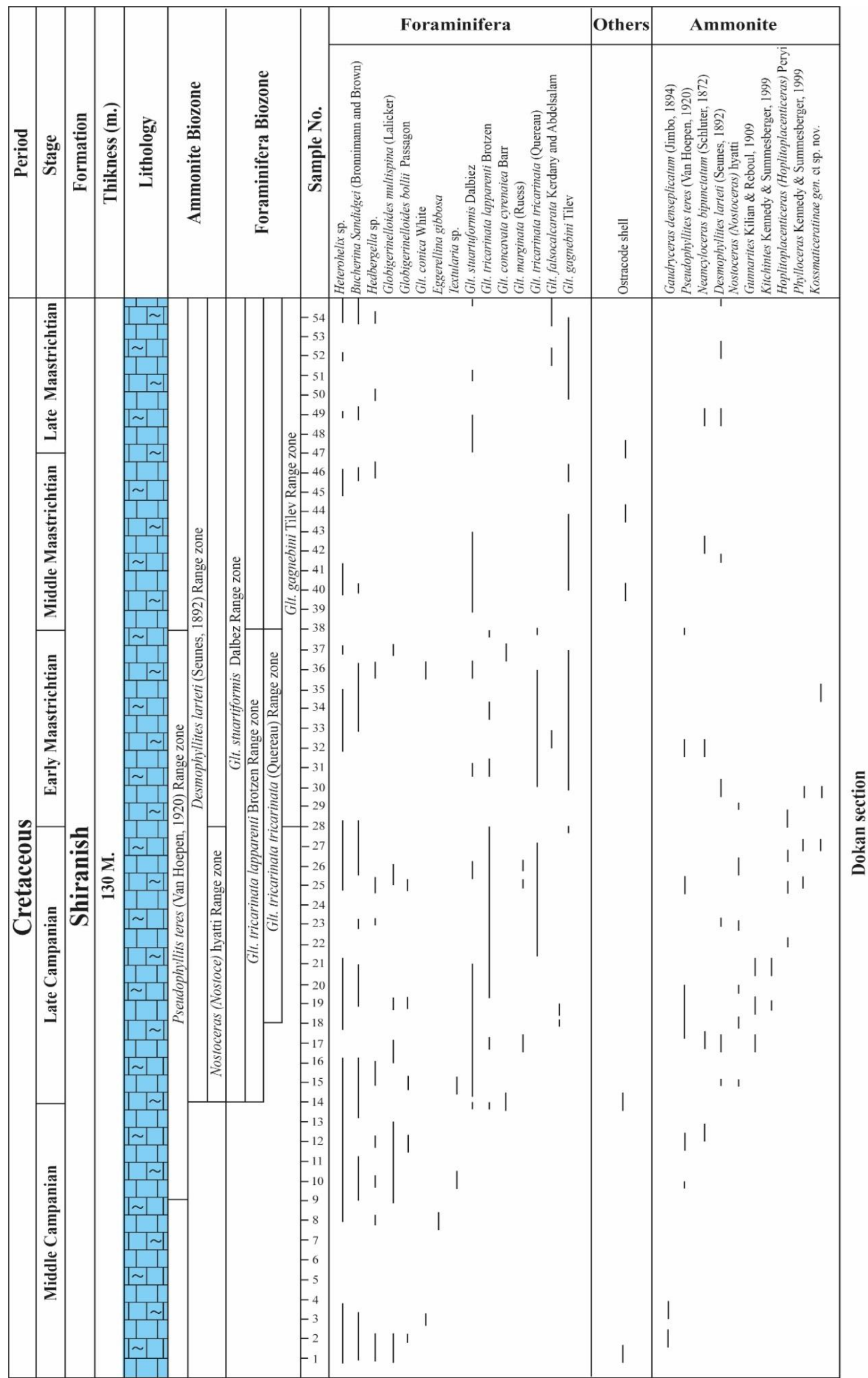

Figure 2-Distribution of Ammonite and Fossils / Dokan section 


\section{Biostratigraphy of Hijran Section}

Different types of macrofauna were identified in the sediments of Shiranish Formation at the Hijran section (Figure3). These include the following Ammonites:

Desmophyllites larteti (Seunes, 1892) (Pl., Figure), Gaudryceras denseplicatum (Jimbo, 1894) (Pl.1, Figures1, 2), Gunnarites Kilian \& Reboul, 1909 (Pl.3, Figures 5, 6), Hoplitoplacenticeras (Hoplitoplacenticeras) Preyi sp. (P1.5, Figure5, 6), Kitchinites Kennedy \& Summesberger, 1999 (P1.2, Figures1, 2), Kossmaticeratinae gen. et sp. nov. (Pl.3, Figures2, 3, 4), Neancyloceras bipunctatum (Schluter, 1872) (Pl.2, Figures3, 4), Neokossmaticeras redondensis sp. nov. (Pl.3, Figure1), Nostoceras (Nostoceras) hyatti (Pl.4, Figures1, 2, 3), Paratexanites serratomarginatus (Redtenbacher, 1873) (Pl.2, Figures5, 6), Partschiceras? Japonicum Matsumoto, 1959 (P1.5, Figures1, 2, 3), Phylloceras Kennedy \& Summesberger, 1999 (Pl., Figure), Pseudophyllites teres (Van Hoepen, 1920) (Pl.4, Figure4,5,6) and Yubariceras yubarense (ex YABE ms.) sp. nov. (P1.5, Figure4).

The identified macrofauna also included the following Foraminifera:

Bucherina sandidgei Bronnimann \& Brown (Pl.10, Figure1 and Pl.13, Figure2), Cibicides sp. (Pl.12, Figure3), Cymopolia sp. (Pl.12, Figure3), Globotruncana Bulloides vogler (Pl.11, Figure6), Globotruncana concavata cyrenaiea Barr (Pl.9, Figure1), Glt falsocalcarata Kerdany and Abdelsalam (Pl.11, Figure4), Glt. Conica white (Pl.11, Figure5), Glt. gagnebini Tilev (P1.9, Figure2), Glt. helvetica Bolli (Pl.12, Figure4), Glt. Marginata (Ruess) (Pl.9, Figure3\& 4), Glt. Stuarti (de Lapparent) (P1.9, Figure5), Glt. Stuartiformis Dalbiez (Pl.11, Figure1), Glt. tricarinata lapparenti Brotzen (Pl.11, Figure2), Glt. tricarinata tricarinata (Quereau) (P1.9, Figure6), Nodosaria sp. (Pl.12, Figure2), Hedbergella sp. (Pl.13, Figure3), Globigerinelloides multispina (Lalicker) (Pl.10, Figures3\&4) Globigerinelloides bollii Passagno (Pl.10, Figure6 and Pl.13, Figure4), Heterohelex sp. (Pl.13, Figure1), Praeglobotruncana cf. delrioensis (Lplummer) (Pl.11, Figure3) and Textularia sp. (Pl.10, Figure2). We also identified othertypes of fossils, such as those of lithoclastic (Pl.13, Figure5), shell fragments (Pl.10, Figure5), and Rotaliid shells (Pl.12, Figure1\&5). 


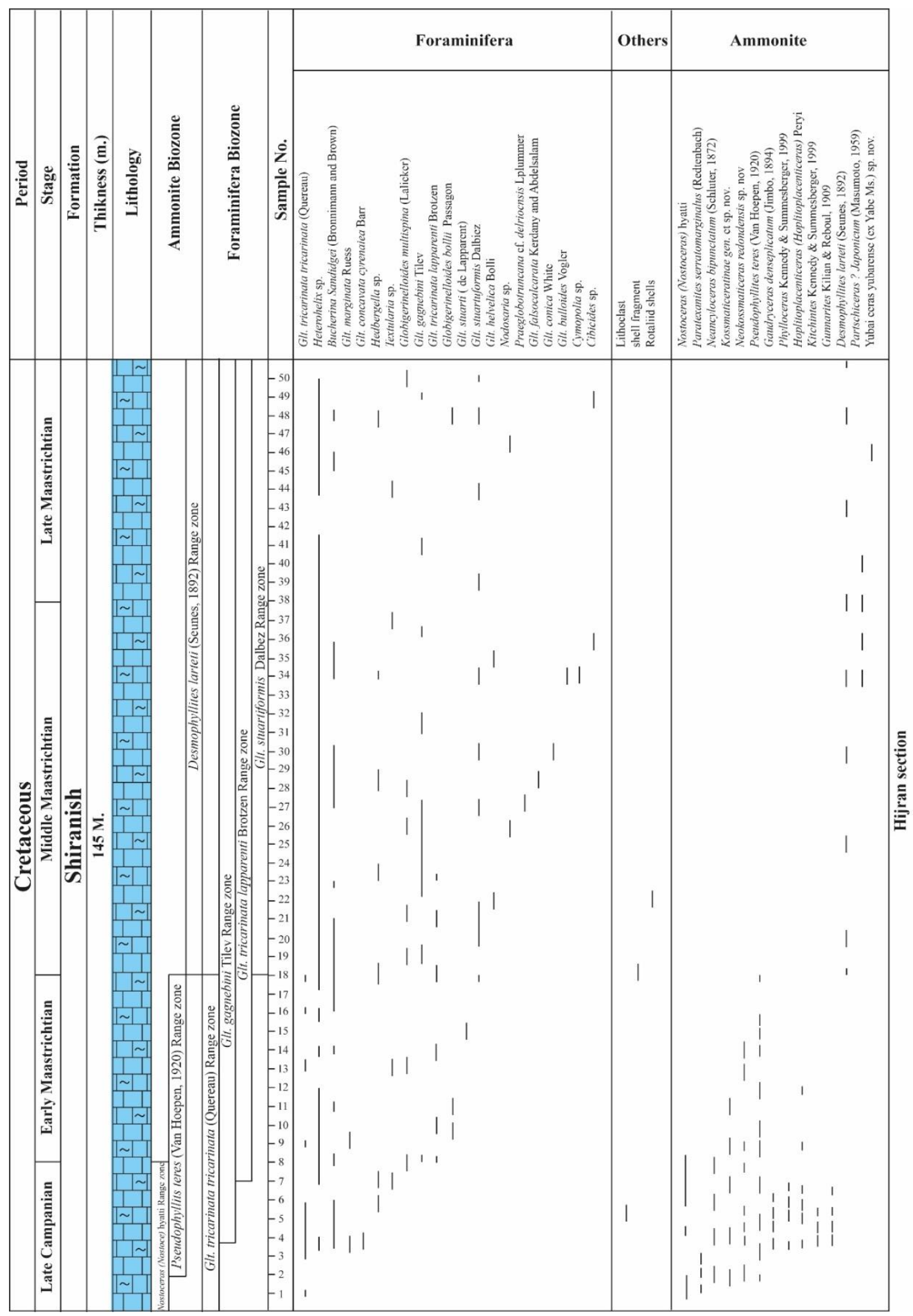

Figure 3-Distribution of Ammonite and Fossils /Hijran section.

\section{Biostratigraphy of Esewa Section}

Several macrofauna were identified in the sediments of Shiranish Formation at the Hijran section (Figure4). These include the following Ammonites:

Desmophyllites larteti (Seunes, 1892) (Pl.1, Figures3, 4), Kitchinites Kennedy \& Summesberger, 1999 (Pl.2, Figures1, 2), Kossmaticeratinae gen. et sp. nov. (Pl.3, Figures2, 3, 4), Neancyloceras bipunctatum (Schluter, 1872) (Pl.2, Figures3, 4), Nostoceras (Nostoceras) 
hyatti (P1.4, Figures1, 2, 3) and Phylloceras Kennedy \& Summesberger, 1999 (Pl.1, Figures5, 6). They also included the following Foraminifera:

Bucherina sandidgei Bronnimann and Brown (Pl.14, Figure1), Cibicides sp. (Pl.14, Figure4), Globigerinelloides multispina (Lalicker) (Pl.15, Figure3), Globigerinelloides bollii Passagno (Pl.14, Figure2, Pl.15, Figure1 and Pl.16, Figure2), Globotruncana gagnebini Tilev (Pl.15, Figure5), Hedbergella sp. (Pl.14, Figure3), Heterohelix sp. (Pl.14, Figure6), Neobulimmina sp. (Pl.15, Figure6), Siphonodosaria sp. (Pl.14, Figure5). Other fossil types were also identified, such as Ostracod shell (Pl.15, Figure4), Rotaliid shells (Pl.15, Figure2) and Echinoderm (Pl.16, Figure1).

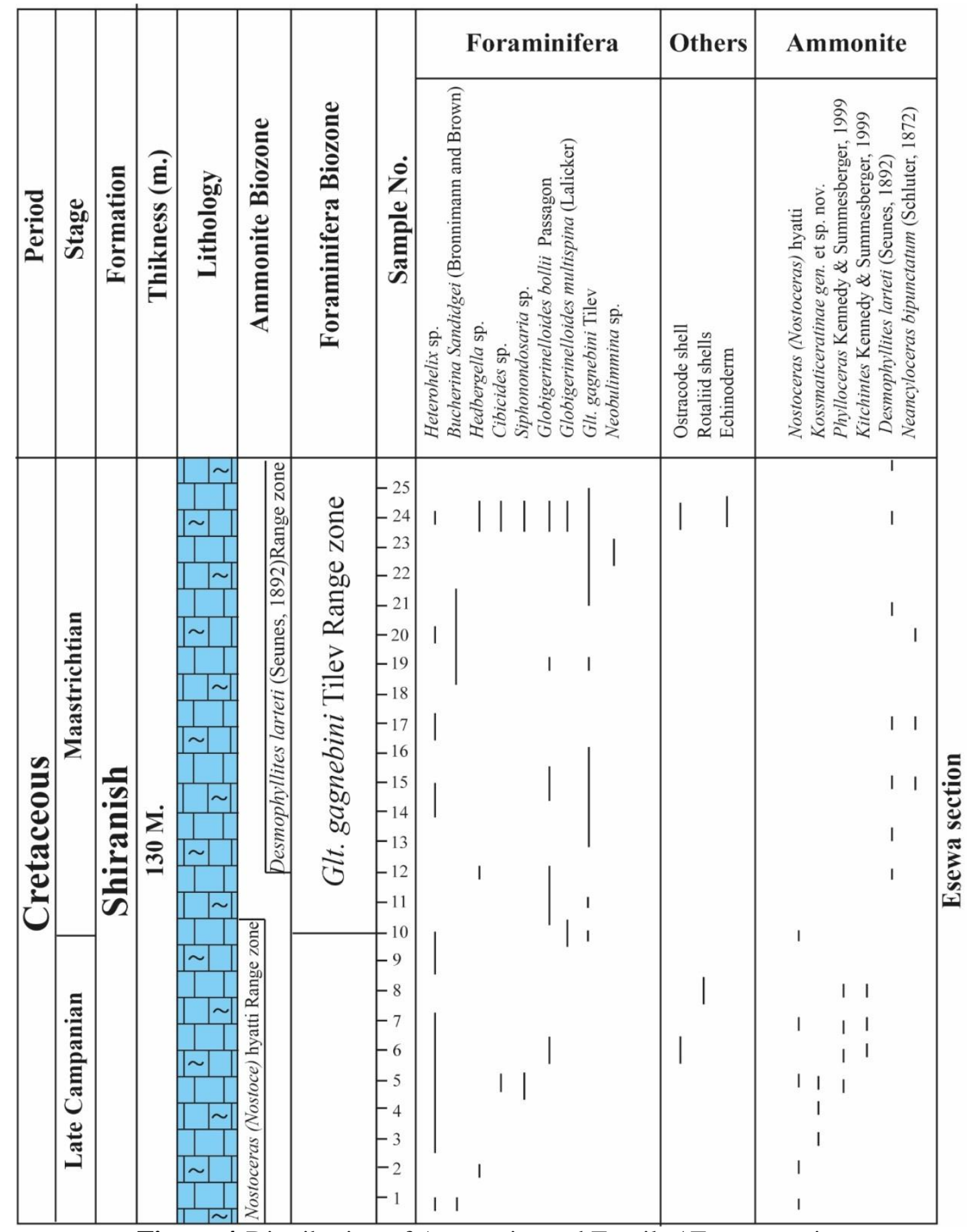

Figure 4-Distribution of Ammonite and Fossils / Esewa section. 


\section{Biostratigraphy of Kanny Dirka Section}

Various microfauna were identified in the sediments of Shiranish Formation at the Kanny dirka section (Figure5). These include the following Foraminifera:

Bucherina sandidgei Bronnimann (P1.17, Figures1\&3), Cibicides sp. (P1.15, Figure3), Eggerellina gibbosa Marie (Pl.16, Figure4 and Pl. 17, Figure4), Elphidium sp. (Pl.20, Figure2), Glt. gagnebini Tilev (Pl.16, Figure3), Globigerinelloides multispina (Lalicker), (Pl.19, Figure3), Hedbergella sp. (Pl.19, Figure4), Heterohelix striata Eherenberge (Pl.19, Figure1), Heterohelex sp. (Pl.19, Figure2), Lenticulina sp (Pl.20, Figure4), Marginulinoposis anstinana (Cushman) (Pl.18, Figure2), Miliolid sp. (Pl.20, Figure1) Nodosaria sp. (Pl.18, Figure1), and others such as: red algae (Pl.17, Figure5), Echinoderm spine (Pl.17, Figure2), Rotalia sp. (Pl.17, Figure6) and Radiolaria (Pl.18, Figure4). 


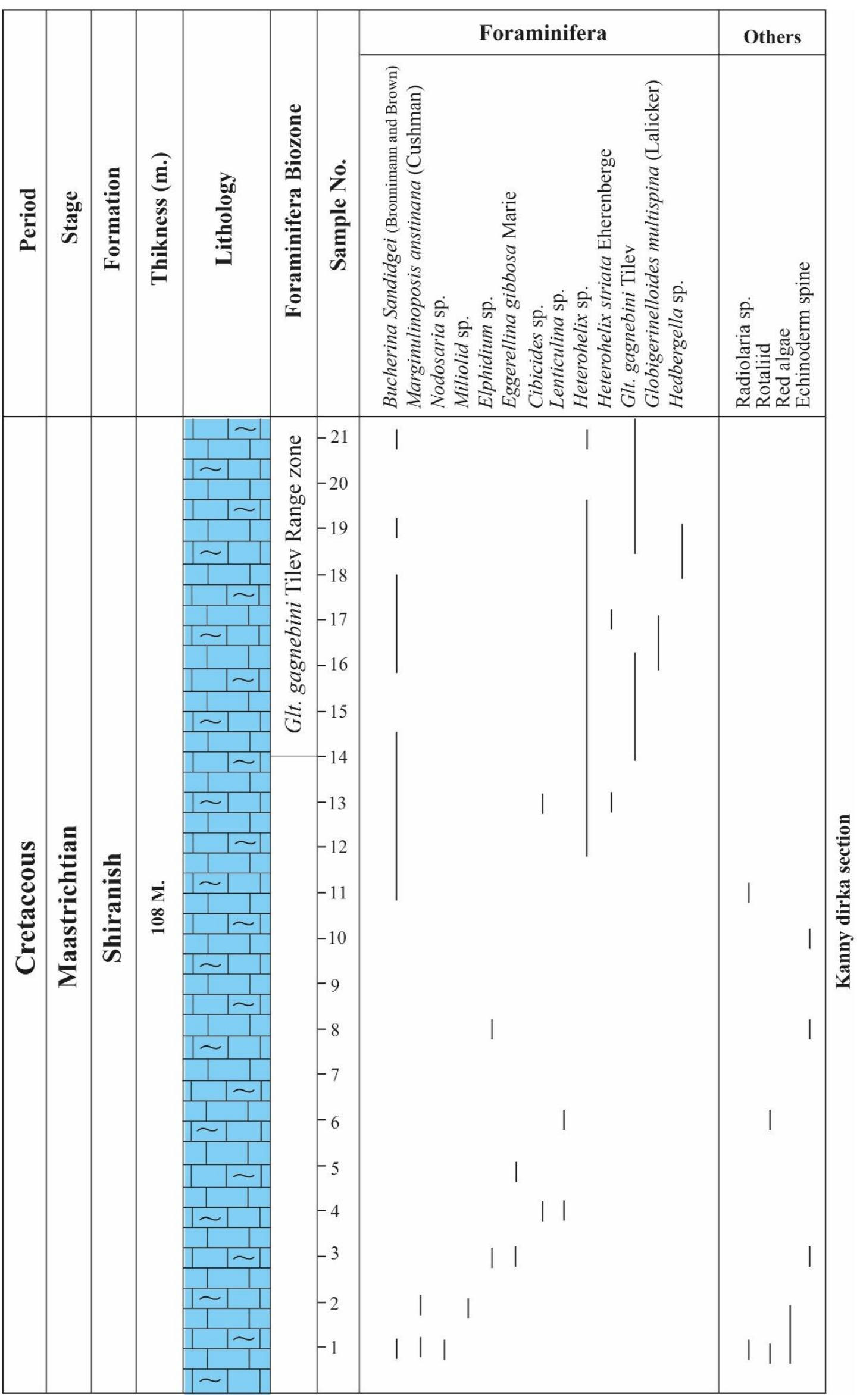

Figure 5-Distribution of Ammonite and Fossils / Kanny dirka section 


\section{Biozones of the studied area}

\section{Ammonite biozones}

The ranges of Ammonites were studied through the stratigraphic sections to determine their biostratigraphic zones. Accordingly, each of the Dokan and Hijran sections were divided into three main biozones, which are pseudophyllites teres (Van Hoepen, 1920) biozone, Desmophyllites larteti (Seunes, 1892) biozone, and Nostoceras (Nostoceras) hyatti, Stephenson, 1941 biozone. While Esewa section was divided into two biozones, which are Desmophyllites larteti (Seunes, 1892) biozone and Nostoceras (Nostoceras) hyatti (Stephenson, 1941) biozone.

\section{Pseudophyllites teres (Van Hoepen, 1920) rang zone}

The lower limit of this biozone is set in accordance with the first appearance of Pseudophyllites teres species, whereas its upper limit coincides with the disappearance of this species. The thickness of the zone is $60 \mathrm{~m}$ in Dokan section and $34 \mathrm{~m}$ in Hijran section. This biozone is coincident with two biozones of Foraminifera within Dokan section, which are Glt. tricarinata lapparenti (Brotzen) biozone and Glt. tricarinata tricarinata (Querean) biozone. In addition, the presence of Nostoceras (Nostoceras) hyatti Stephenson, 1941 Ammonite biozone was recorded, as well as the presence of the following fossils:

Gunnarites Kilian \& Reboul, 1909, Kritchinites Kennedy \& Summesberger, 1999, Hoplitoplacenticeras (Hoplitoplacenticeras) Preyi sp., Phylloceras Kennedy \& Summesberger, 1999 and Kossmaticeratinae gen. et. sp. nov.

As for Hijran section, it was found to be coincident with Glt. tricarinata tricarinata (Quereau) foraminifera biozone, in addition to the presence of Nostoceras (Nostoceras) hyatti Stephenson, 1941 Ammonite biozone and the following fossils:

Gaudryceras denseplicatum (Jimbo, 1894), Phylloceras Kennedy \& Summesberger, Hoplitoplacenticeras (Hoplitoplacenticeras) Preyi sp., 1999, Kritchinites Kennedy \& Summesberger, 1999 and Gunnarites Kilian \& Reboul, 1909. However, the disappearance of this section is coincident with the appearance of Desmophyllites larteti (Seunes, 1892) Ammonite biozone.

\section{Age of Pseudophyllites teres (Van Hoepen, 1920) rang zone}

The age of this zone is dependent on the recorded age of the species Pseudophyllites teres in other countries [9], which showed that the range of this species is from the late Santonian to the early Campanian. This range has to be extended to the late Campanian, on the basis of the Gschliefgraben specimen. The geographic range of the species involves Pondoland (South Africa), Madagascar, and possibly Brazil. In the percent study, the age of this zone was determined to be the late Campanian- early Maastrichtian in Dokan and Hijran sections.

\section{Desmophyllites larteti (Seunes, 1892) rang zone}

The lower limit of this zone is determined based on the first appearance of this species. Its upper limit coincides with the disappearance of the species (until the sections end). The thickness of the zone is $82 \mathrm{~m}$ in Dokan section, $66 \mathrm{~m}$ in Hijran section, and $28 \mathrm{~m}$ in Esewa section.

This biozone is coincident with Glt. stuartiformis Dalbies biozones of foraminifera, along with the presence of foraminfera biozones within Dokan section, which are Glt. tricarinata lapparenti Brotzen biozone, Glt. tricarinata tricarinata (Querean) biozone and Glt. gagenbini Tilev biozones.

In addition, we recorded the presence of Nostoceras (Nostoceras) hyatti Stephenson, 1941 Ammonite biozone and the following fossils:

Gunnarites Kilian \& Reboul, 1909, Kritchinites Kennedy \& Summesberger, 1999, Hoplitoplacenticeras (Hoplitoplacenticeras) Preyi sp., Phylloceras Kennedy \& Summesberger, 1999 and Kossmaticeratinae gen. et. sp. nov. 
As for Hijran section, it is coincident with the appearance of Glt. Stuartiformis Dalbies biozone of foraminifera and with the disappearance of Pseudophyllites teres (Van Hoepen, 1920) ammonite biozone and Glt. tricarinata tricarinata (Quereau) foraminfera biozone. In addition, the presence of the fossils of Partschiceras? Japonicum (Motsumoto) and Yubariceras yubarense (ex yabe ms.) sp. nov. was observed within this biozone.

As for Esewa section, it is coincident with the appearance of Glt. gagnebini Tilev foraminifera biozone and with the disappearance of Nostoceras (Nostoceras) hyatti ammonite biozone. It also contains the fossil Neancyloceras bipunctatum.

Age of Desmophyllites larteti (Seunes, 1892) rang zone

The age of this zone was determined depending on the occurrence of this species within sediments belonging to Campanian- Maastrichtian age in Iraq and other countries. This zone was recorded to belong to the late Campanian to late Maastrichtian in Pyrenees- Atlantiques and Landes in France, the coastal sections of the Biscay region of France and NW Spain, the Gschliefgraben, Austria, and possibly Madagascar [10]; it also ranges from early Maastrichtian to late Maastrichtian of Madagascar [11]. In the present study, it was determined to the late Campanian- late Maastrichtian within Dokan section, middle Maastrichtian- late Maastrichtian within Hijran section, and Maastrichtian within Esewa section.

\section{Nostoceras (Nostoceras) hyatti Stephenson, 1941 rang zone}

The lower limit of this zone was determined based on the first appearance of this species and its upper limit coincides with the disappearance of the species. The thickness of the zone is 30 $\mathrm{m}$ in Dokan section, $16 \mathrm{~m}$ in Hijran section, and $20 \mathrm{~m}$ in Esewa section.

This biozone is present within two ammonite biozones, which are Desmophyllites larteti (Seunes, 1892) biozone and Pseudophyllites teres (Van Hoepen, 1920) biozone, within Dokan section. It also contains the following fossils:

Gunnarites Kilian \& Reboul, 1909, Kritchinites Kennedy \& Summesberger, 1999 and Hoplitoplacenticeras (Hoplitoplacenticeras) Preyi sp.

As for Hijran section, it is located within the Pseudophyllites teres (Van Hoepen, 1920) zone and contains the fossils of Paratexanites serratomarginatus (Redtenbach) and Neancyloceras bipunctatum (Schluter, 1872).

The disappearance of this biozone is coincident with the appearance of two foraminifera biozones, which are Glt. gagnebini Tilev biozone and Glt. tricarinata lapparenti Brotzen biozone. Within Esewa section, the disappearance of this biozone is coincident with the appearance of Desmophyllites larteti (Seunes, 1892) Ammonite biozone and Glt. gagnebini Tilev Foraminfera biozone. In addition, it contains the following fossils:

Kossmaticeratinae gen. et sp. nov., Phylloceras Kennedy \& Summesberger, 1999 and Kitchinites Kennedy \& Summesberger, 1999.

\section{Age of Nostoceras (Nostoceras) hyatti Stephenson, 1941 rang zone}

The age of this zone is dependent on the age of the species Nostoceras (Nostoceras) hyatti in Iraq and other countries. This species is widespread worldwide and represents the last range of the Campanian age, where the period after its last appearance was that of the beginning of the Maastrichtean [12]. These countries include France, the United States of America, Spain, Belgium, Poland, Angola, Madagascar, Palestine, and Iraq [13, 14]. Also, it was recorded to belong to the late Campanian age in the lower part of Shiranish Formation, NW Iraq [15]. In the percent study, the age of this zone was determined to be the late Campanian within each of Dokan, Hijran, and Esewa sections, depending on the age of the species Nostoceras (Nostoceras) hyatti.

\section{Foraminifera biozones}

Through the detailed biostratigraphic study of Shiranish Formation, depending on the 
presence of planktonic and benthonic foraminifera, four biozones were recognized in each of Dokan and Hijran sections, which are Globotruncana Stuartiformis Dalbiez biozone, Glt. tricarinata lapparenti Brotzen biozone, Glt. tricarinata tricarinata (Querean) biozone, and Glt. gagnebini Tilev biozon . Also, Glt. gagnebini Tilev biozone was recorded in Esewa and Kanny dirka sections. The description and discussion of the biozones are manifested below,

\section{Globotruncana stuartiformis Dalbiez rang zone}

This zone is identified depending on the range of extension of Glt. stuariformis species. The lower limit of the zone was identified according to the occurrence of this species, whereas the upper limit was determined based on the last appearance. The thickness of the biozone is 82 $m$ in Dokan section and $66 \mathrm{~m}$ in Hijran section.

Within Dokan section, this biozone includes the Foraminfera biozones of Glt. tricarinata lapparenti Brotzen, Glt. tricarinata tricarinata (Querean), and Glt.gagnebini Tilev. The appearance of this biozone is coincident with the appearance of Glt. tricarinata lapparenti Brotzen biozone. It also included the fossils of Glt. concavata cyrenaiea, Glt. marginata (Ruess), and Globigerinelloides bollii Passagno.

Within Hijran section, the appearance of this biozone is coincident with the disappearance of Glt. tricarinata tricarinata (Quereau) biozone. The section was within Glt. gagnebini Tilev biozone and includes the following fossils: Globigerinelloides bollii Passagno, Glt. helvetica Bolli, Nodosaria sp., Praeglobotruncana cf. delrioensis (Lplummer), Glt. falsocalcarata Kerdany and Abdelsalam, Glt. conica White, Glt. bulloides Vogler, Cymopolia sp., and Cibicides sp.

\section{Age of the Globotruncana stuartiformis Dalbiez rang zone}

The age of this zone was determined to be dependent on the age of the species Glt. stuartiformis in Iraq and other countries. In north- east Iraq, Glt. stuartiformis is one of the abundant species of Globotruncana, observed in the Shiranish Formation (CampanianMaastrichtian) [16] and Maastrichtian within Sinjar area [17]. The species was originally described to be from the Campanian- early Maastrichtian strata of Tunisia. It is also known from the strata of similar ages in Texas and Puerto Rico [18-20], New Jersey [21], and the Maestrichtian of Egypt [22]. Glt. stuartiformis was also recorded from the CampanianMaastrichtian of Europe and Russia. Dalbiez [23] described Glt. stuartiformis as a subspecies of Glt.elevata (Brotzen) from the Campanian- Lower Maastrichtian of Tunisia [24]. In the present study, it was determined to belong to the late Campanian- late Maastrichtian in Dokan section and middle Maastrichtian- late Maastrichtian within Hijran section.

\section{Globotruncana tricarinata lapparenti Brotzen rang zone}

This zone is identified depending on the range of extension of Glt. tricarinata lapparenti subspecies. The lower limit of this zone is determined based on the first appearance of this species and its upper limit coincides with disappearance of the species. The thickness of the biozone is $50 \mathrm{~m}$ in Dokan section and $32 \mathrm{~m}$ in Hijran section.

In Dokan section, this biozone is within Glt. stuartiformis Dalbies biozone and includes Glt. tricarinata tricarinata Brotzen biozone along with the fossils of Glt. concavata cyrenaiea, Glt. marginata (Ruess) and Globigerinelloides bollii Passagno.

Within Hijran section, the appearance of this biozone is coincident with the appearance of Glt. gagnebini Tilev biozone and includes the fossils of Globigerinelloides multispina (Lalicker) and Glt. Stuartiformis (de' lapparent).

Age of Glt. tricarinata lapparenti Brotzen rang zone

This biozone is recorded depending on the occurrence of this species within sediments in Iraq and other countries, as in the following:

This species is recorded from the Campanian portion of the Shiranish Formation where it occurs rather commonly [16]. De Lapparent's original figures are of specimens from strata within the Turonian to Campanian interval in Europe. The subspecies is also recorded from 
strata of early Santonian to early Maastrichtian age of Mexico and Texas [20], SantonianCampanian of Puerto Rico [18, 19], and Santonian- Lower Maestrichtian of Trinidad [25]. It is also known in the strata of the similar age in Russia [26], Australia [16, 27, 28], and North Africa [29]. In the present study, it was determined in the late Campanian- early Maastrichtian within Dokan section and early Maastrichtian- middle Maastrichtian within Hijran section.

\section{Globotruncana tricarinata tricarinata (Querean) rang zone:}

The lower limit of this zone is set in accordance with the first appearance of this species and its upper limit coincides with the disappearance of the species. The thickness of the biozone is $42 \mathrm{~m}$ in Dokan section and $36 \mathrm{~m}$ in Hijran section.

In Dokan section, this biozone is within Glt. stuartiformis Dalbies biozone and Glt. tricarinata lapparenti Brotzen biozone.

Within Hijran section, the disappearance of this biozone coincides with the appearance of Glt. stuartiformis Dalbies biozone and includes the fossils of Globigerinelloides multispina (Lalicker) and Glt. Stuarti (de' lapparent).

\section{Age of Glt. tricarinata tricarinata (Querean) rang zone}

The age of this zone was determined depending on the occurrence of this species within sediments recorded in Iraq and other countries, as follows:

Glt. tricarinata tricarinata occurs rather commonly in Campanian portions of the Shiranish Formation [16]. The species was originally described from Campanian to early Maestrichtian strata of Switzerland. Bolli [25] and [30] used the subspecies as a distinctive zonal marker for the Campanian- early Maastrichtian strata of Trinidad and the subsurface Campanian- early Maastrichtian. Strata uncounted in Leg 15 sites in the Caribbean Sea. It is also described from the Campanian of the Carnarvon Basin, north- west Ausralia [27], the Santonian of England [31], and the Campanian- early maestrichtian of Libya [29, 32]. According to previous reports $[16,33]$, the subspecies is also recorded from the type Campanian section at Aubeterre in the Aquitain Basin. It is also known in the strata of lower Maastrichtian age in New Jersey [21]. Turonian- Maastrichtian worldwide [24, 34] determined the age from the late Maastrichtian of north and west Iraq. In the present study, it is determined in the late Campanian- early Maastrichtian age within each of Dokan and Hijran sections.

\section{Globotruncana gagnebini Tilev rang zone}

The lower limit of this zone is set in accordance with the first appearance of this species and its upper limit coincides with the disappearance of the species. The thickness of the biozone is $54 \mathrm{~m}$ in Dokan section, $84 \mathrm{~m}$ in Hijran section, $32 \mathrm{~m}$ in Esewa section, and $16 \mathrm{~m}$ in Kanny dirka section.

In Dokan section, this biozone is within Glt. stuartiformis Dalbies biozone. Within Hijran section, the appearance of this biozone coincides with the appearance of Glt. tricarinata lapparenti biozone and includes each of Glt. tricarinata lapparenti Brotzen and Glt. Stuartiformis Dalbies biozones. It also includes the following fossils: Globigerinelloides multispina (Lalicker), Globigerinelloides bollii Passagno, Glt. stuarti (de Lapparent), Glt. helvetica Bolli, Nodosaria sp., Praeglobotruncana cf. delrioensis (Lplummer), Glt. falsocalcarata Kerdany and Abdelsalam, Glt. conica White, Glt. bulloides Vogler, Cymopolia sp., and Cibicides sp. Within Esewa section, this biozone includes Neobulimmina sp. fossils, whereas within Kanny dirka section, it includes Globigerinelloides multispina (Lalicker), Hedbergella sp., and Bucherina sandidgei Bronnimann fossils.

\section{Age of Globotruncana gagnebini Tilev rang zone}

The age of this zone was determined depending on the occurrence of this species within sediments belonging to the Maastrichtian age in Iraq and other countries.

The specimens are identical to the specimen figured by an earlier study [21] from the Maastrichtian strata of New Jersey. In the present study, it is determined in the early 
Maastrichtian- late Campanian within Dokan and Hijran sections and the Maastrichtian within Esewa and Kanny dirka sections.

\section{Discussion and conclusions}

Fourteen species of Ammonites belonging to fourteen genera were identified from the three study sections (Dokan, Hijran, and Esewa). In addition, thirty- five species of Foraminfera (planktonic and benthonic) belonging to thirteen genera were recognized in the four sections (Dokan, Hijran, Esewa, and Kanny dirka) in Shiranish Formation .

Seven range zones were determined at the studied work, three of them are Ammonites, which are Desmophyllites larteti (Seunes, 1892), Nostoceras (Nostoceras) hyatti and Pseudophyllites teres (Van Hoepen, 1920), and the others are Foraminifers, which are Glt. gagnebini Tilev, Glt. tricarinata lapparenti Brotzen, Glt. tricarinata tricarinata (Querean) and Glt. Stuartiformis Dalbiez. And according with these biozones, the age of Shiranish Formation was determined as the Late Campanian- Maastrichtian.

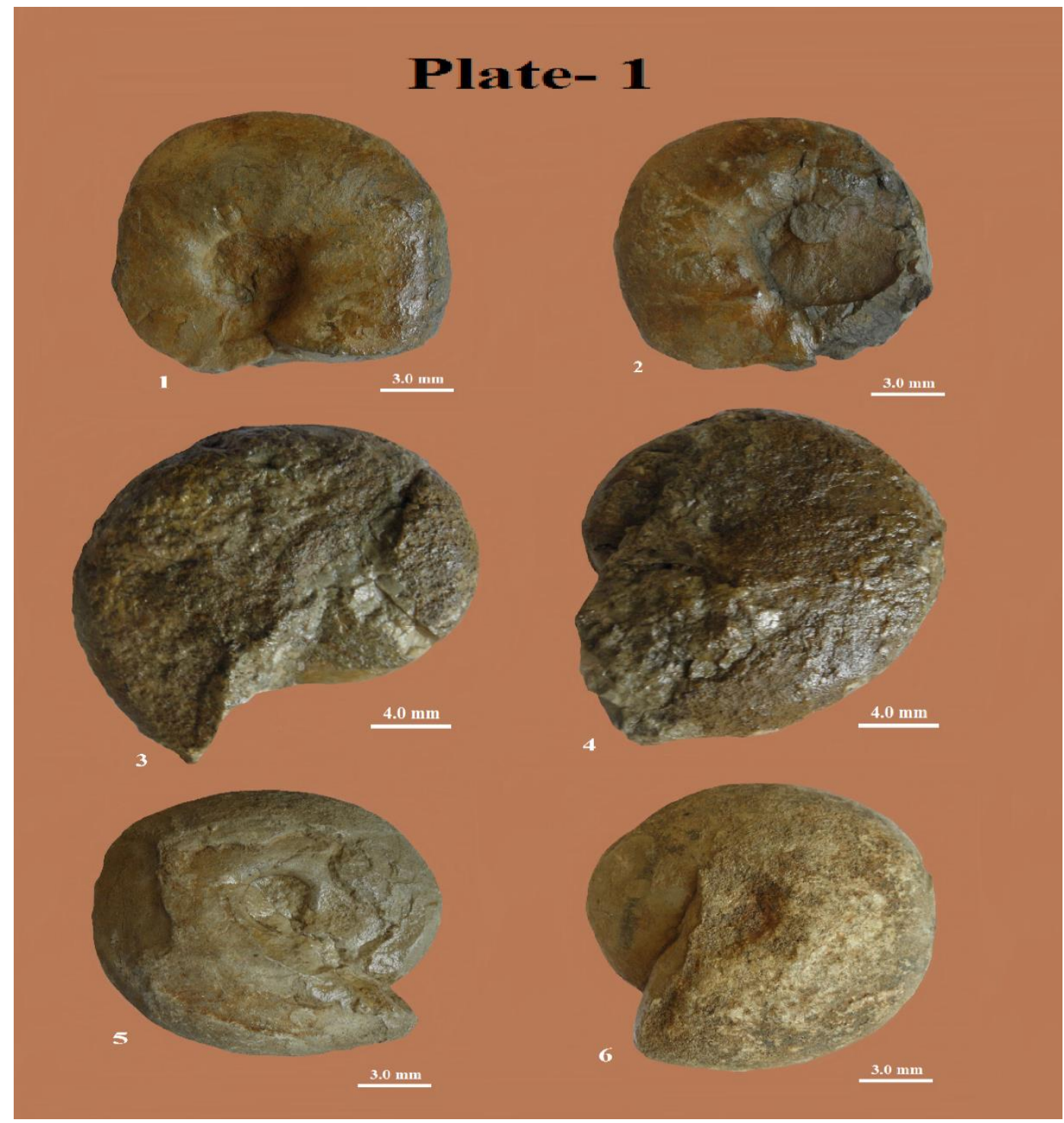

Plate 1-Shiranish Formation. Gaudryceras denseplicatum (Jimbo, 1894); Figure 1: B.U.A. 1, side view, Dokan section, sample no. 2; Figure 2: B.U.A. 2, side view, Dokan section, sample no. 2. Desmophyllites larteti (Seunes, 1892); Figure 3: B.U.A. 3, side view, Dokan section, sample no. 13; Figure 4: B.U.A. 4, side view, Dokan section, sample no. 13. Phylloceras Kennedy \& Summesberger, 1999; Figure 5: B.U.A. 5, side view, Dokan section, sample no. 25; Figure 6: B.U.A. 6, side view, Dokan section, sample no. 25. 


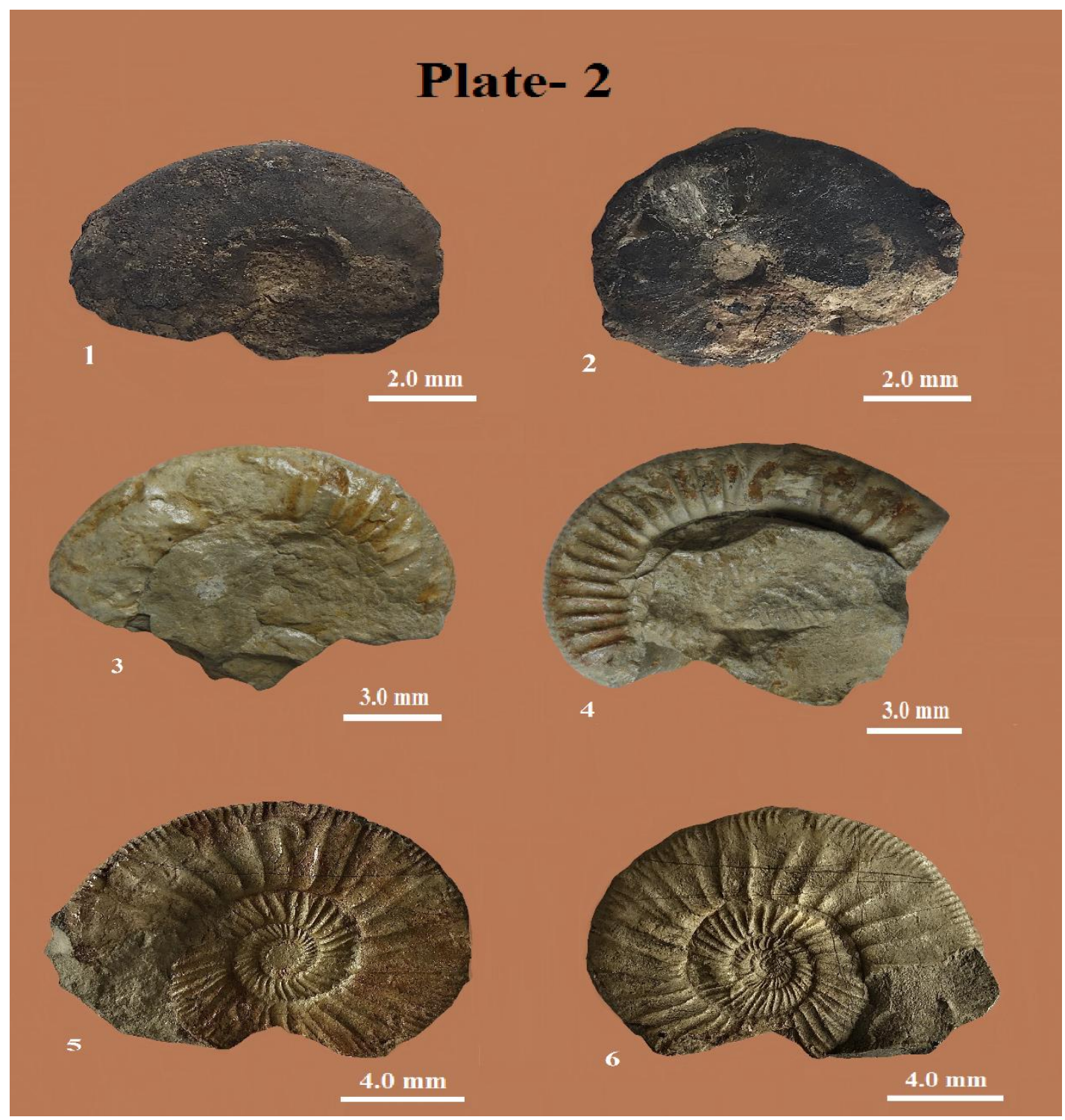

Kitchinites Kennedy \& Summesberger, 1999

Figure 1 B.U.A. 7, side view, Esewa section, sample no. 6, Shiranish Formation.

Figure 2 B.U.A. 8, side view, Esewa section, sample no. 6, Shiranish Formation.

Neancyloceras bipunctatum (Schluter, 1872)

Figure 3 B.U.A. 9, side view, Dokan section, sample no. 30, Shiranish Formation. Figure 4 B.U.A. 10, side view, Dokan section, sample no. 30, Shiranish Formation. Paratexanites serratomarginatus (Redtenbacher, 1873)

Figure 5 B.U.A. 11, side view, Hijran section, sample no. 3, Shiranish Formation. Figure 6 B.U.A. 12, side view, Hijran section, sample no. 3, Shiranish Formation. 


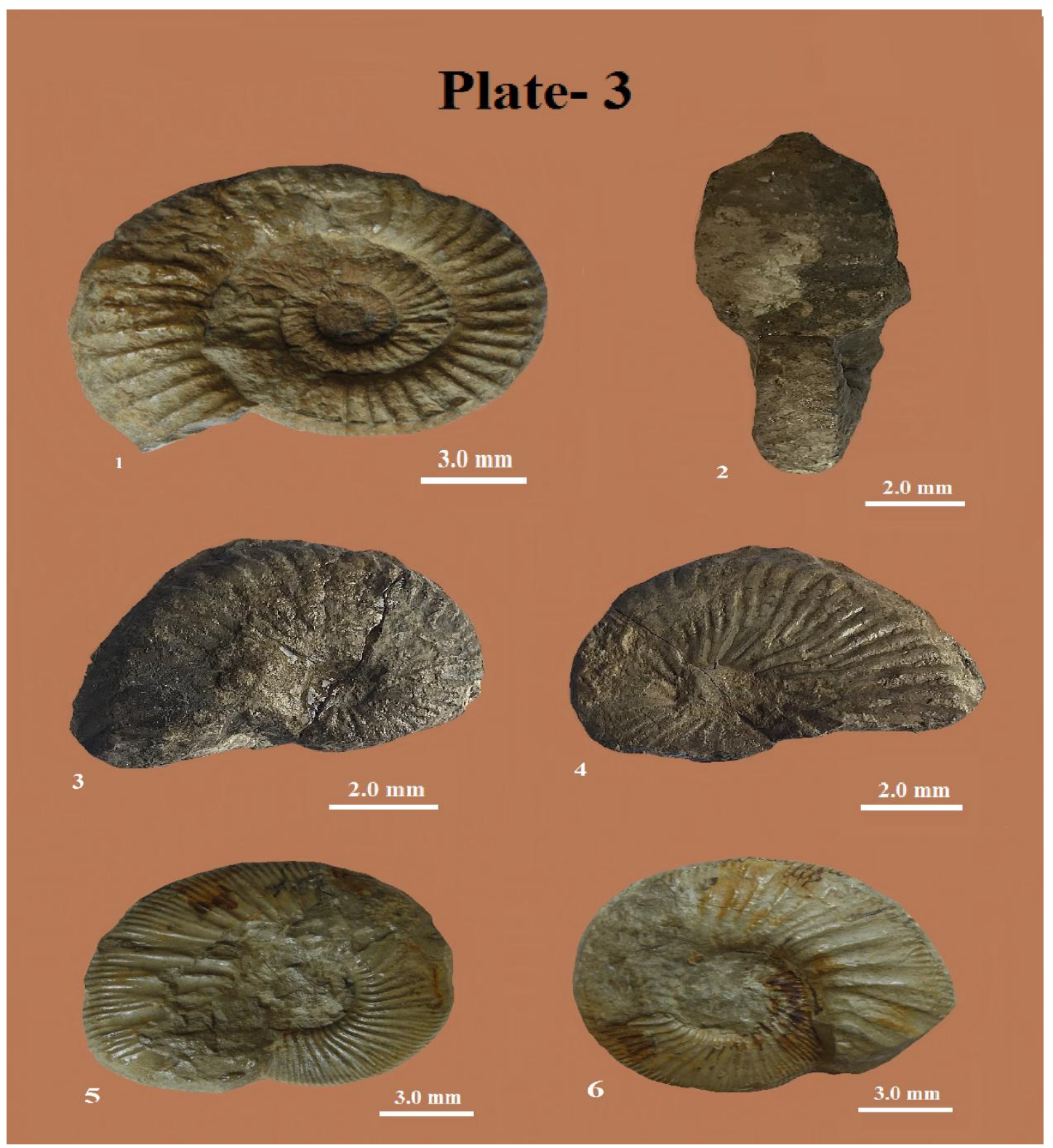

\section{Neokossmaticeras redondensis sp. nov.}

Figure 1 B.U.A. 13, side view, Hijran section, sample no. 4, Shiranish Formation. Kossmaticeratinae gen. et. sp. nov.

Figure 2 B.U.A. 14, apertural view, Esewa section, sample no. 5, Shiranish Formation. Figure 3 B.U.A. 15, side view, Esewa section, sample no. 5, Shiranish Formation. Figure 4 B.U.A. 16, side view, Esewa section, sample no. 5, Shiranish Formation.

Gunnarites Kilian \& Reboul, 1909

Figure5 B.U.A. 17, side view, Dokan section, sample no. 15, Shiranish Formation. Figure 6 B.U.A. 18, side view, Dokan section, sample no. 15, Shiranish Formation. 


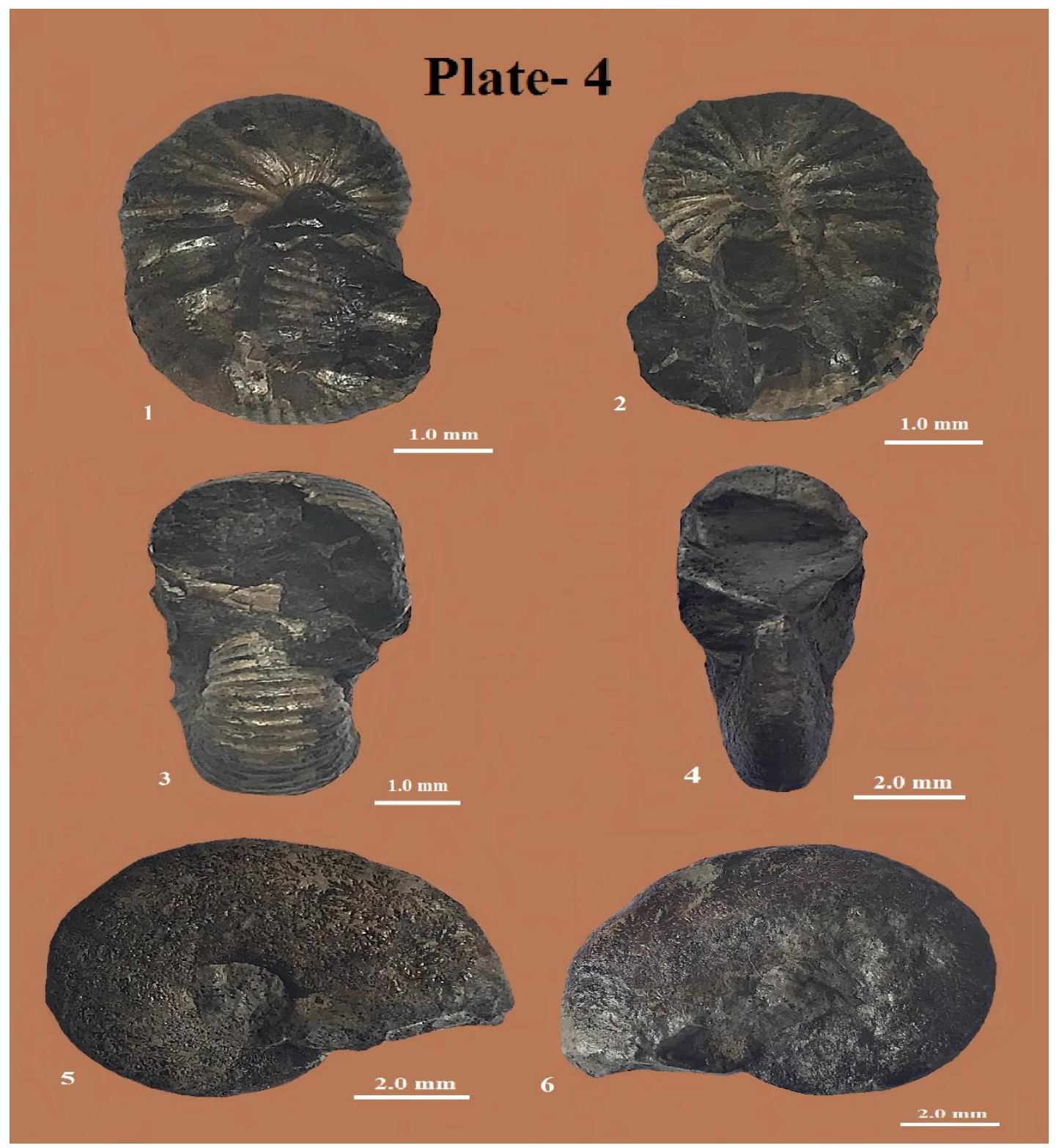

\section{Pseudophylliites teres (Van Hoepen, 1920)}

Figure 1 B.U.A. 19, side view, Hijran section, sample no. 10, Shiranish Formation. Figure 2 B.U.A. 20, side view, Hijran section, sample no. 10, Shiranish Formation. Figure 3 B.U.A. 21, apertural view, Hijran section, sample no. 10, Shiranish Formation. Nostoceras (Nostoceras) hyatti

Figure 4 B.U.A. 22, apertural view, Dokan section, sample no. 18, Shiranish Formation. Figure 5 B.U.A. 23, side view, Dokan section, sample no. 18, Shiranish Formation. Figure 6 B.U.A. 24, side view, Dokan section, sample no. 18, Shiranish Formation. 


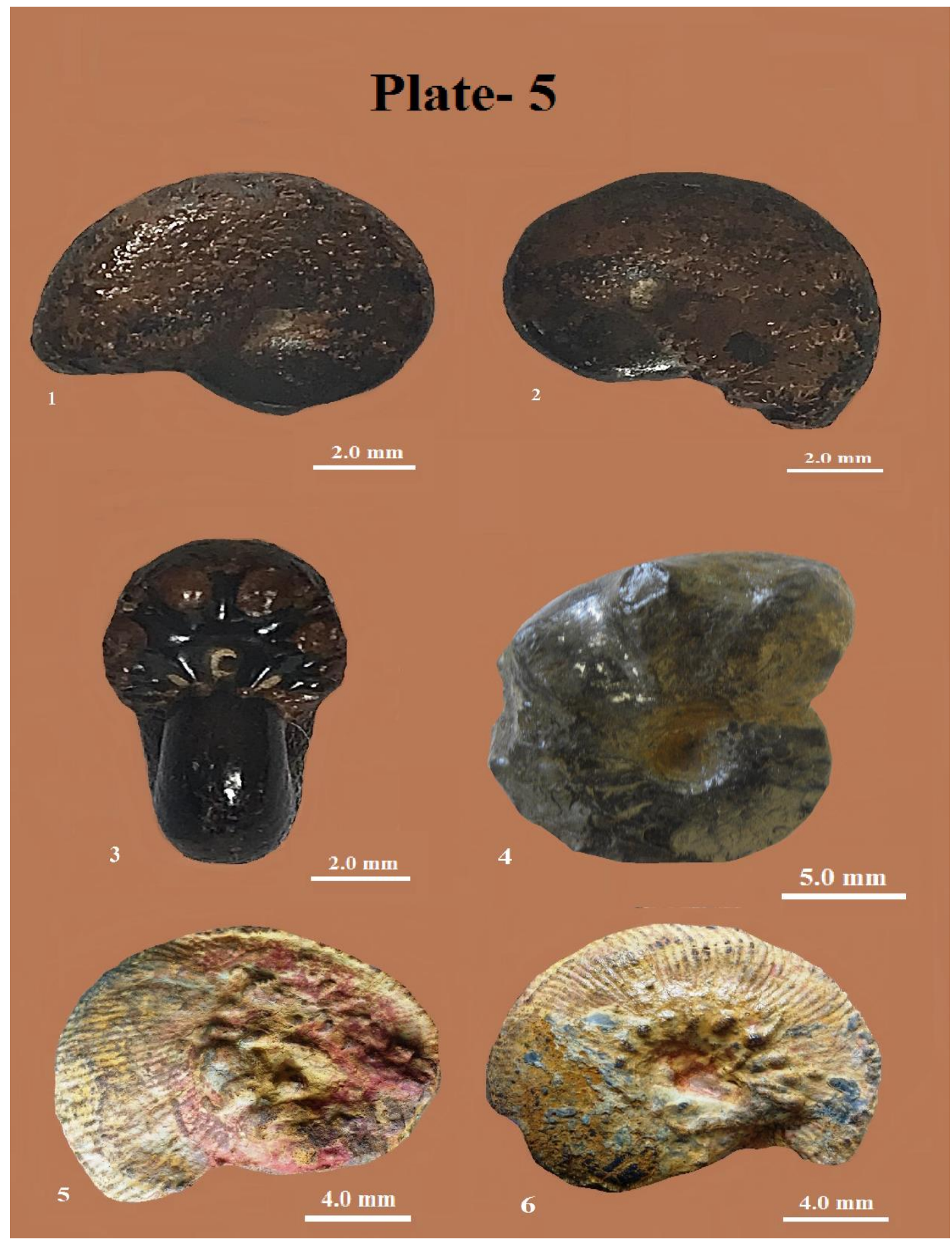

\section{Partschiceras? Japonicum (Matsumoto, 1959)}

Figure 1 B.U.A. 25, side view, Hijran section, sample no. 40, Shiranish Formation. Figure 2 B.U.A. 26, side view, Hijran section, sample no. 40, Shiranish Formation. Figure 3 B.U.A. 27, apertural view, Hijran section, sample no. 40, Shiranish Formation. Yubartceras yubarense (ex yabe ms.) sp. nov.

Figure 4 B.U.A. 28, side view, Hijran section, sample no. 46, Shiranish Formation. Hoplitoplacenticeras (Hoplitoplacenticeras) preyi sp.

Figure 5 B.U.A. 29, side view, Dokan section, sample no. 20, Shiranish Formation. Figure 6 B.U.A. 30, side view, Dokan section, sample no. 20, Shiranish Formation. 

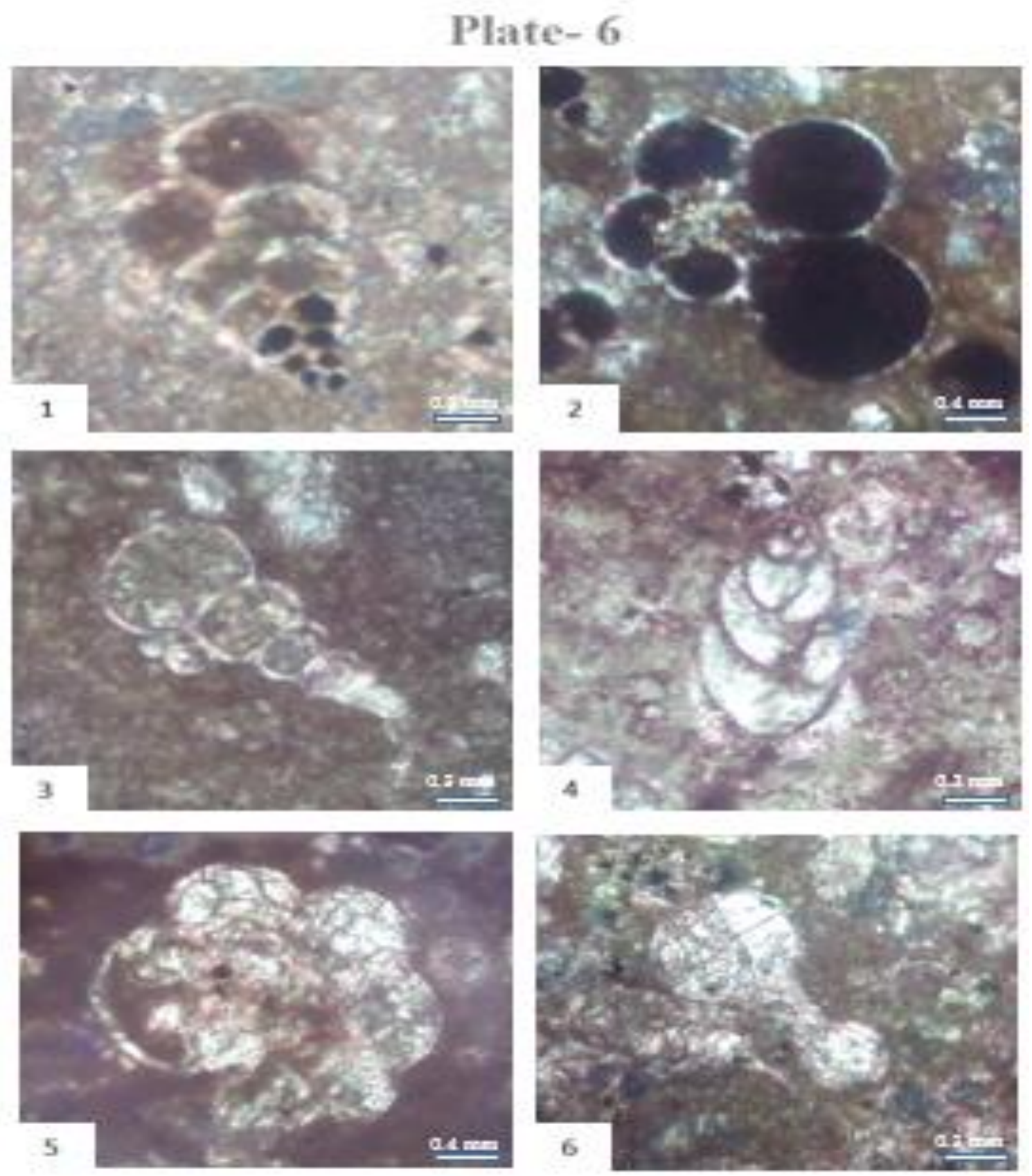

Figure 1 Textularia sp., Dokan section, sample no. 15, Shiranish Formation.

Figure 2 Globigerinelloides multispina (Laliker), Dokan section, sample no. 46, Shiranish Formation.

Figure 3 Heterohelix sp., Dokan section, sample no. 27, Shiranish Formation.

Figure 4 Eggerellina gibbosa Marie, Dokan section, sample no. 8, Shiranish Formation.

Figure 5 Globigerinelloides multispina (Laliker), Dokan section, sample no. 11, Shiranish Formation.

Figure 6 Hedbergella sp., Dokan section, sample no. 10, Shiranish Formation. 

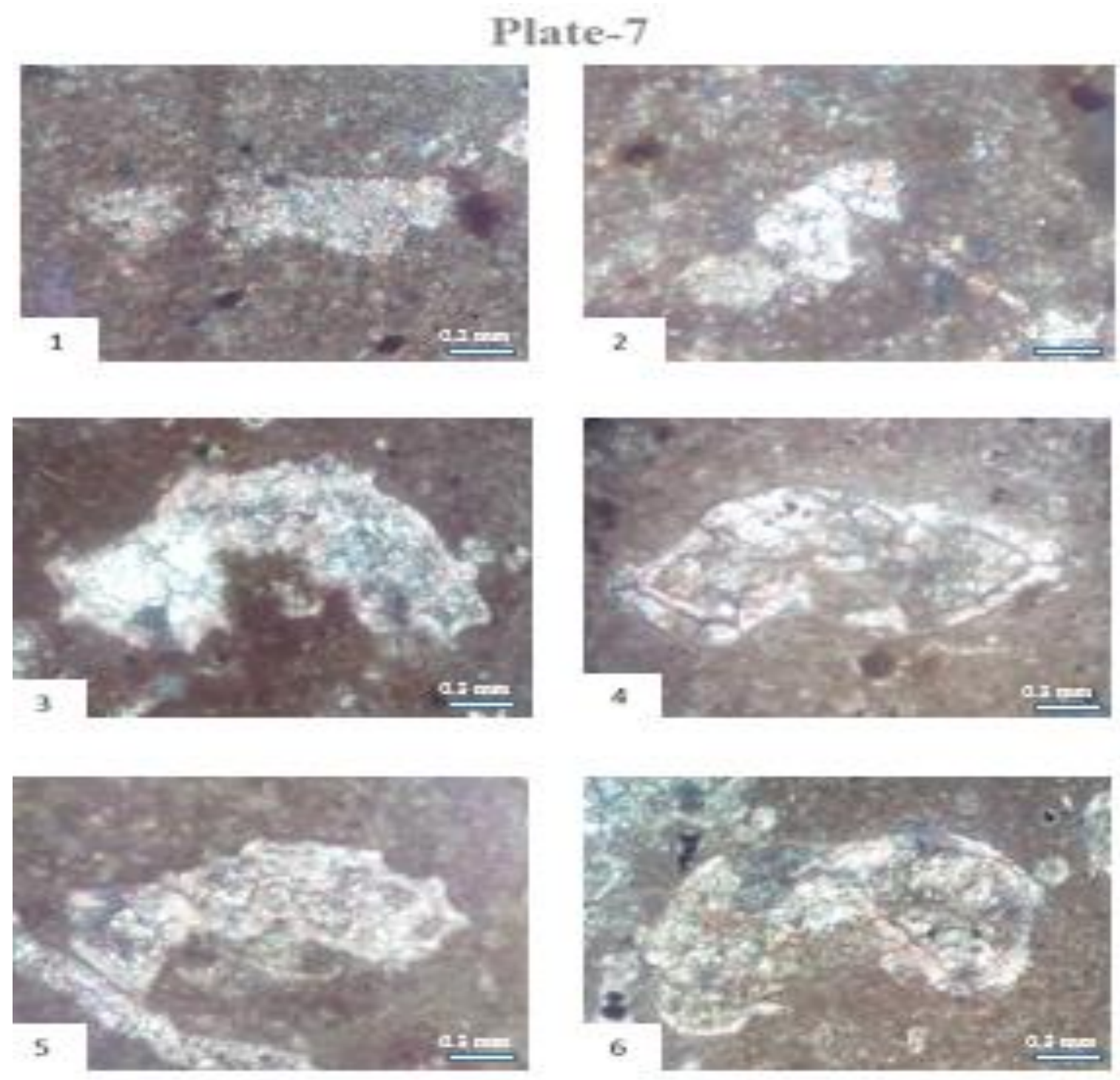

Figure 1 Glt. falsocalcarata Kerdany and Abdelsalam, Dokan section, sample no. 32, Shiranish Formation.

Figure 2 Glt. gagnebini Tilev, Dokan section, sample no. 46, Shiranish Formation.

Figure 3 Glt. tricarinata tricarinata (Quereau), Dokan section, sample no. 19, Shiranish Formation.

Figure 4 Glt. marginata (Ruess), Dokan section, sample no. 17, Shiranish Formation.

Figure 5 Glt. tricarinata lapparenti Brotzen, Dokan section, sample no. 34, Shiranish Formation.

Figure 6 concavata cyrenaiea Barr, Dokan section, sample no. 14, Shiranish Formation. 


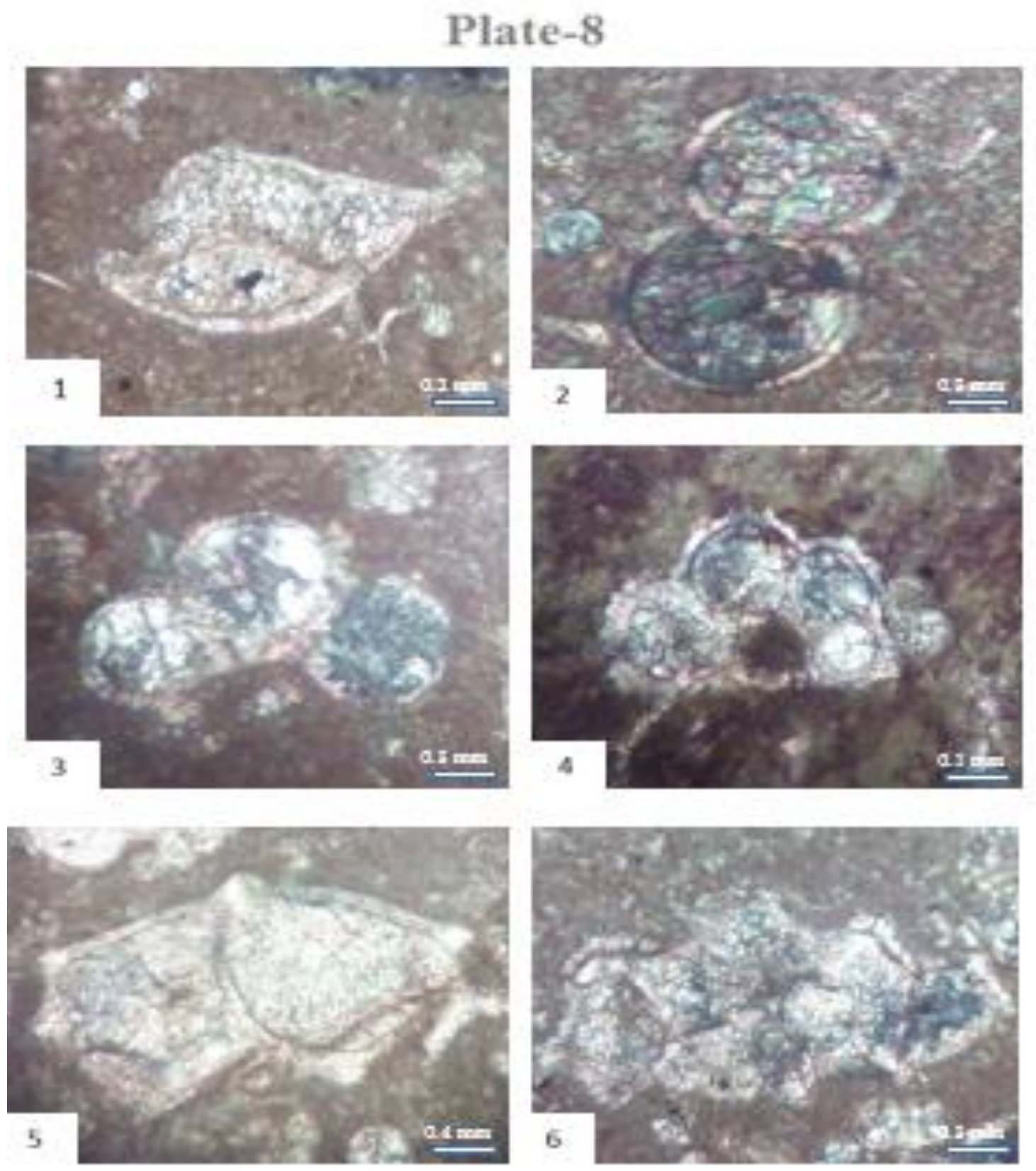

Figure 1 Ostracoda shell, Dokan section, sample no. 14, Shiranish Formation.

Figure 2 Bucherina sandidgei Bonnimann and Brown, Dokan section, sample no. 1, Shiranish Formation.

Figure 3 Globigerinelloides bollii Passagno, Dokan section, sample no. 19, Shiranish Formation.

Figure 4 Globigerinelloides bollii Passagno, Dokan section, sample no. 55, Shiranish Formation.

Figure 5 Glt. conica white, Dokan section, sample no. 03, Shiranish Formation.

Figure 6 Glt. Stuartiformis Dalbies, Dokan section, sample no. 14, Shiranish Formation. 


\section{Plate-9}
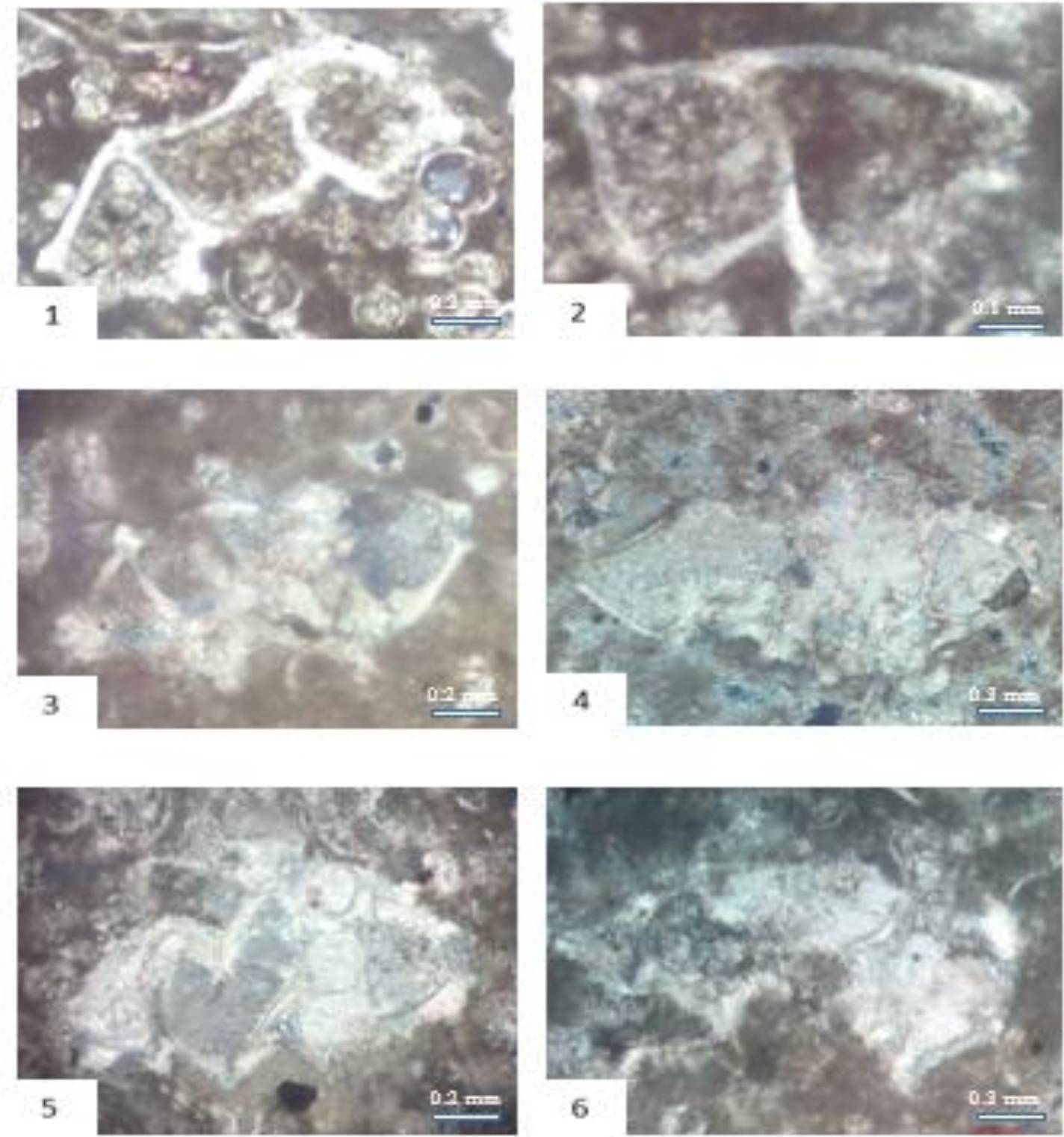

Figure 1 Glt. concavata cyrenaiea Barr, Hijran section, sample no. 4, Shiranish Formation. Figure 2 Glt. gagnebini Tilev, Hijran section, sample no. 4, Shiranish Formation. Figure 3 Glt. marginata (Ruess), Hijran section, sample no. 9, Shiranish Formation. Figure 4 Glt. marginata (Ruess), Hijran section, sample no. 12, Shiranish Formation. Figure 5 Glt. Stuarti (de Lapparent), Hijran section, sample no. 15, Shiranish Formation. Figure 6 Glt. tricarinata tricarinata (Quereau), Hijran section, sample no. 18, Shiranish Formation. 


\section{Plate-10}
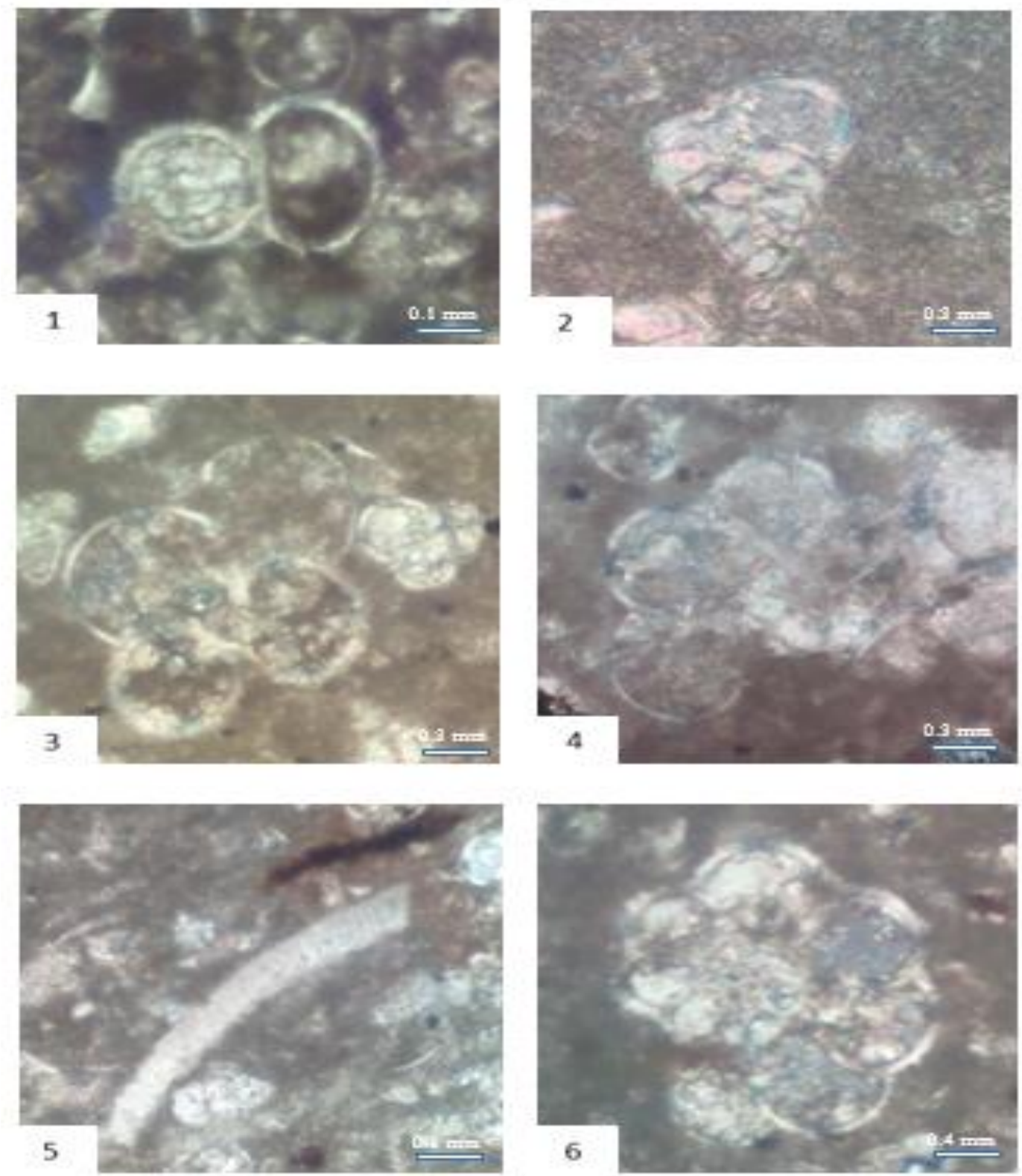

Figure 1 Bucherina sandidgei Bronnimann \& Brow., Hijran section, sample no. 4, Shiranish Formation.

Figure 2 Textularia sp., Hijran section, sample no. 7, Shiranish Formation.

Figure 3 Globigerinelloides multispina (Lalicker), Hijran section, sample no. 9, Shiranish Formation.

Figure 4 Globigerinelloides multispina (Lalicker), Hijran section, sample no. 9, Shiranish Formation.

Figure 5 Shell fragments, Hijran section, sample no. 18, Shiranish Formation.

Figure 6 Globigerinelloides bollii Passagno, Hijran section, sample no. 18, Shiranish Formation. 


\section{Plate-11}
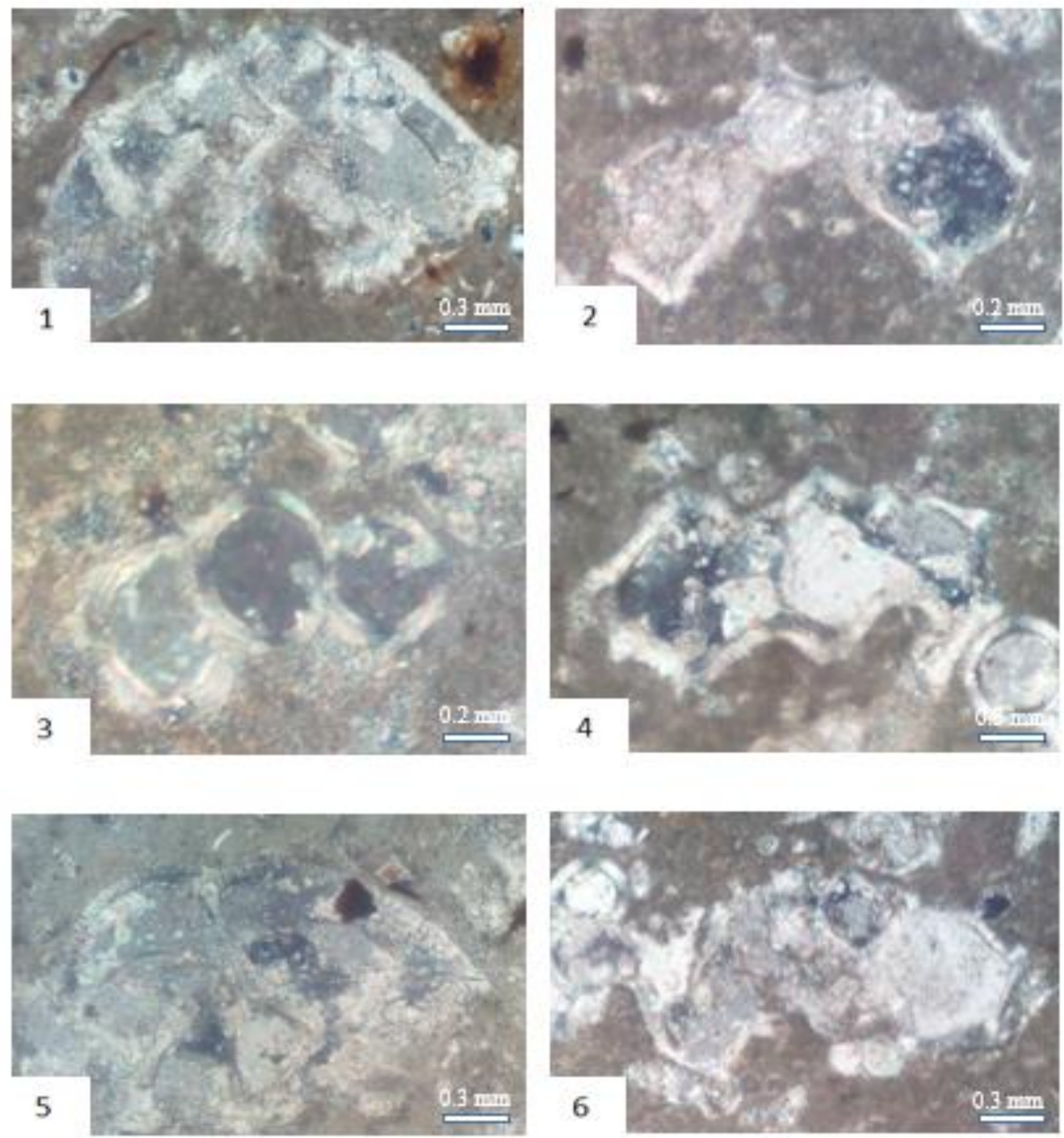

Figure 1 Glt. Stuartiformis Dalbiez, Hijran section, sample no. 34, Shiranish Formation. Figure 2 Glt. tricarinata lapparenti Brotzen, Hijran section, sample no. 23, Shiranish Formation.

Figure 3 Praeglobotruncana cf. delrioensis (Lplummer), Hijran section, sample no. 27, Shiranish Formation.

Figure 4 Glt. falsocalcarata kerdany and Abdelsalam, Hijran section, sample no. 28, Shiranish Formation.

Figure 5 Conica white, Hijran section, sample no. 30, Shiranish Formation.

Figure 6 Glt. bulloides volger, Hijran section, sample no. 34, Shiranish Formation. 


\section{Plate-12}
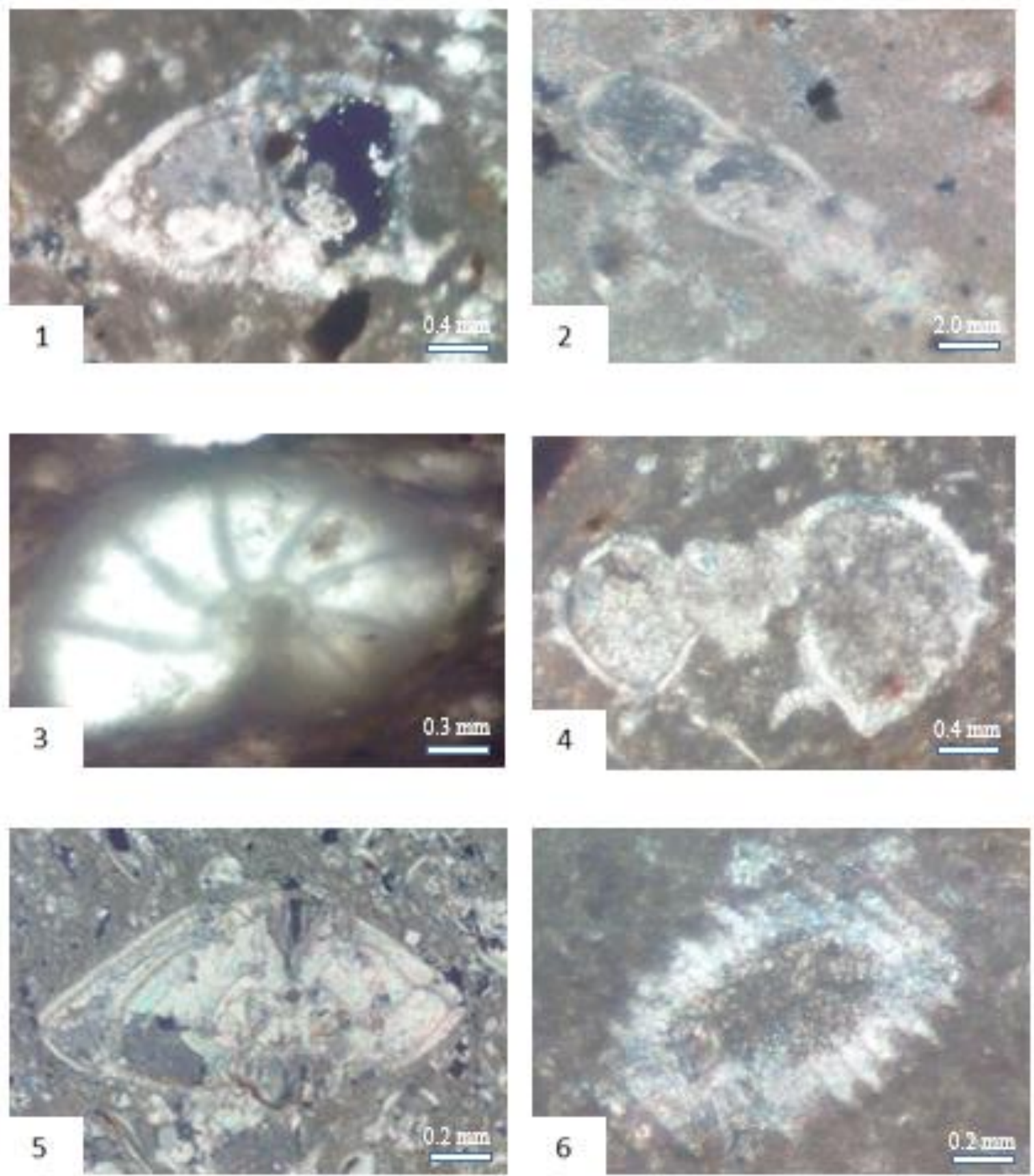

Figure 1 Rotalid sp., Hijran section, sample no. 22, Shiranish Formation.

Figure 2 Nodosaria sp., Hijran section, sample no. 26, Shiranish Formation.

Figure 3 Cibicides sp., Hijran section, sample no. 49, Shiranish Formation.

Figure 4 Helvetica Bolli, Hijran section, sample no. 35, Shiranish Formation.

Figure 5 Rotaliid shell, Hijran section, sample no. 41, Shiranish Formation.

Figure 6 Cymopolia sp., Hijran section, sample no. 34, Shiranish Formation. 


\section{Plate-13}
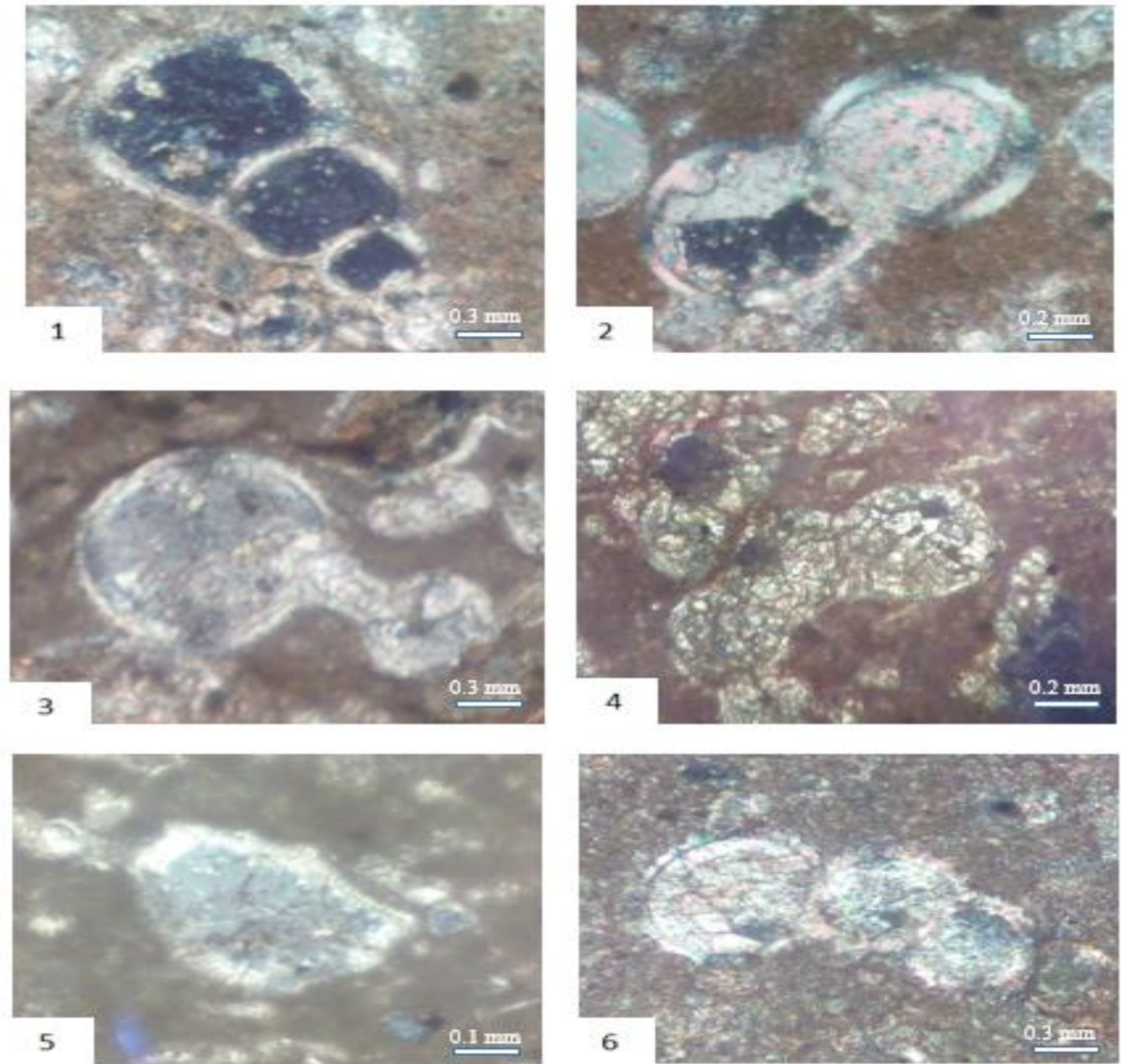

Figure 1 Heterohelix sp., Hijran section, sample no. 50, Shiranish Formation.

Figure 2 Bucherina sandidgei Bronnimann and Brown, Hijran section, sample no. 11, Shiranish Formation.

Figure 3 Hedbergella sp., Hijran section, sample no. 48, Shiranish Formation.

Figure 4 Globigerinelloides bollii Passagno, Hijran section, sample no. 48, Shiranish Formation.

Figure 5 Lithoclast, Hijran section, sample no. 05, Shiranish Formation.

Figure 6 Globigerinelloides bollii Passagno, Dokan section, sample no. 15, Shiranish Formation. 


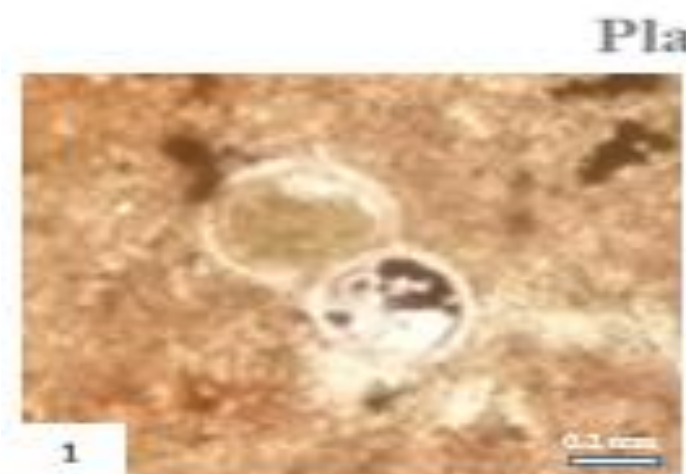

Plate-14
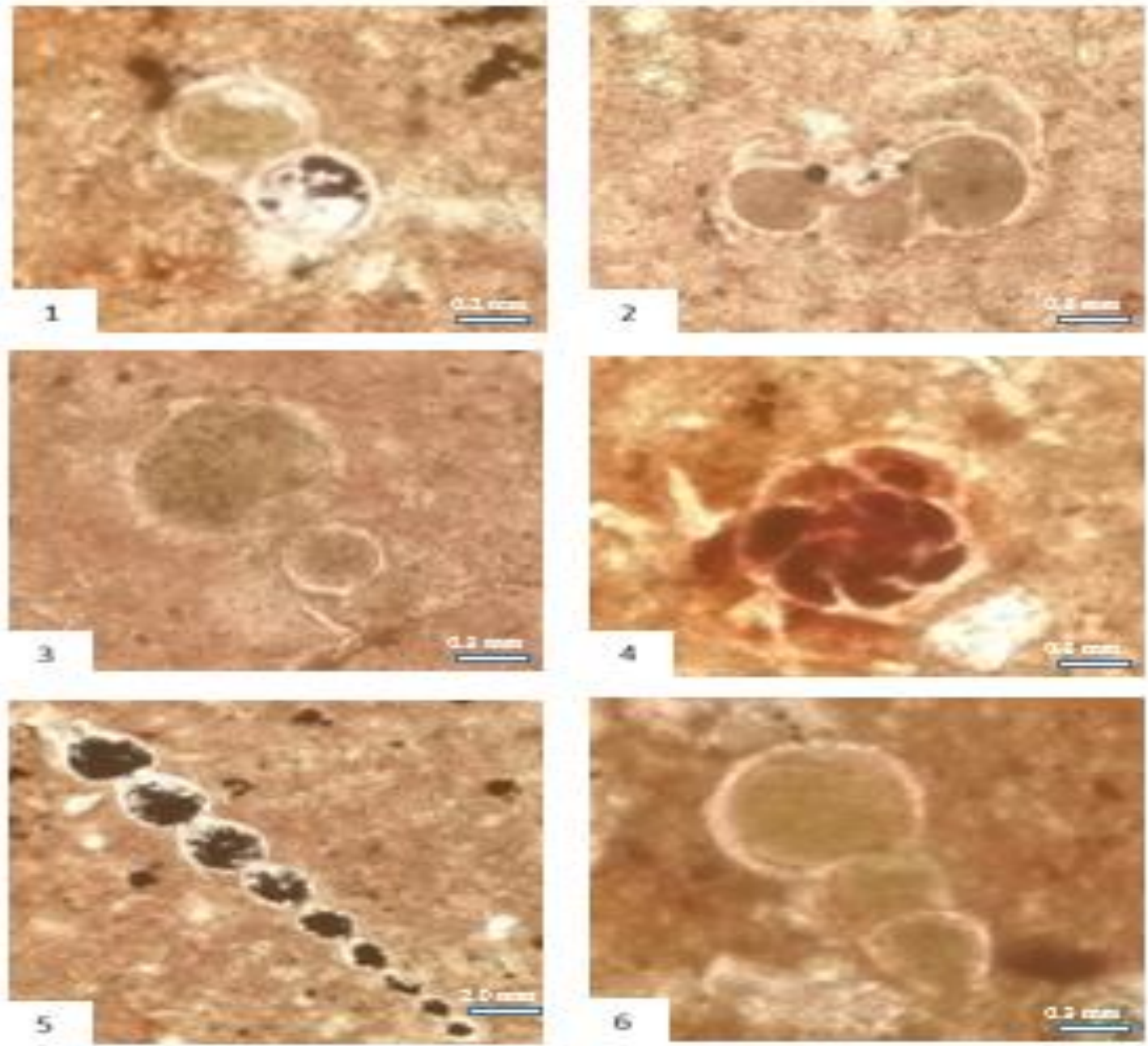

Figure 1 Bucherina sandidgei Bronnimann and Brown, Esewa section, sample no. 1, Shiranish Formation.

Figure 2 Globigerinelloides bollii Passagno, Esewa section, sample no. 7, Shiranish Formation.

Figure 3 Hedbergella sp., Esewa section, sample no. 2, Shiranish Formation.

Figure 4 Cibicides sp., Esewa section, sample no. 5, Shiranish Formation.

Figure 5 Siphonodosaria sp., Esewa section, sample no. 5, Shiranish Formation.

Figure 6 Heterohelix sp., Esewa section, sample no. 24, Shiranish Formation. 


\section{Plate-15}
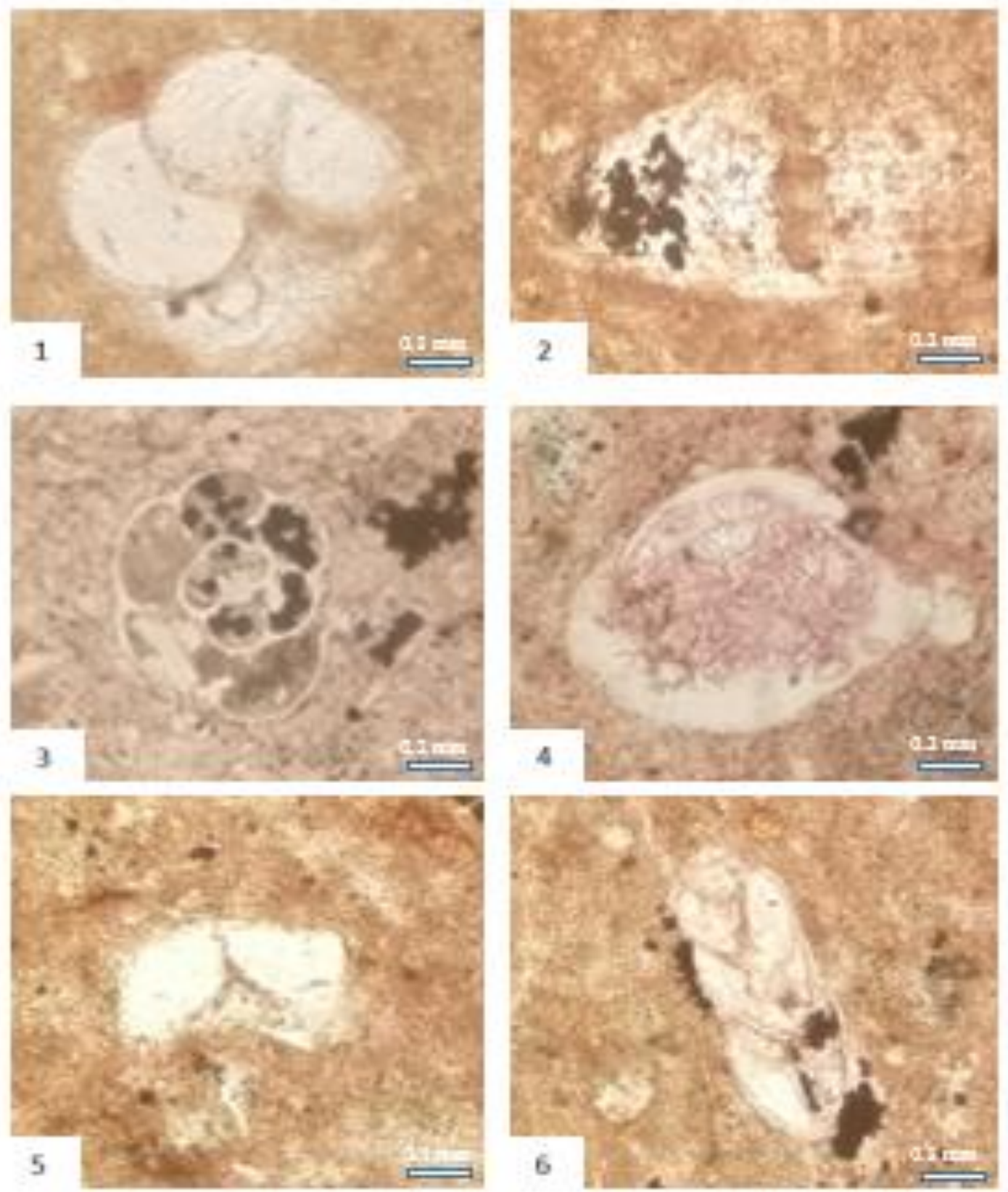

Figure 1 Globigerinelloides bollii Passagno, Esewa section, sample no. 8, Shiranish Formation.

Figure 2 Rotalid shell, Esewa section, sample no. 8, Shiranish Formation.

Figure 3 Globigerinelloides multispina (Lalicker), Esewa section, sample no. 10, Shiranish Formation.

Figure 4 Ostracoda shell, Esewa section, sample no. 6, Shiranish Formation.

Figure 5 Glt. gagnebini Tilev, Esewa section, sample no. 11, Shiranish Formation.

Figure 6 Neobulimmina sp., Esewa section, sample no. 11, Shiranish Formation. 


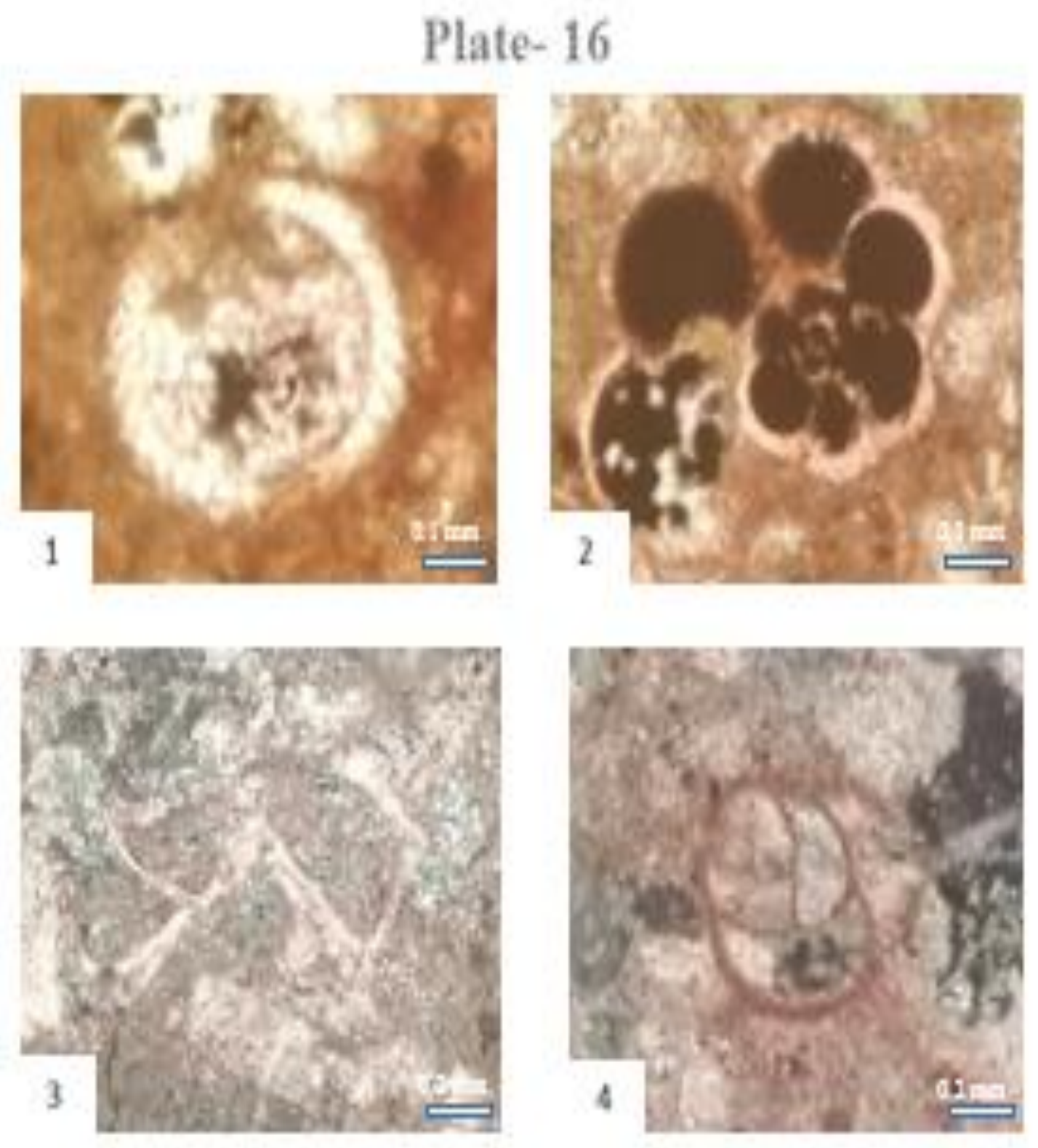

Figure 1 Echinoderm spine, Esewa section, sample no. 24, Shiranish Formation.

Figure 2 Globigerinelloides bollii Passagno, Esewa section, sample no. 24, Shiranish Formation.

Figure 3 Glt. gagnebini Tilev, Kanny dirka section, sample no. 16, Shiranish Formation. Figure 4 Eggerellina gibbosa Marie, Kanny dirka section, sample no. 6, Shiranish Formation. 


\section{Plate-17}

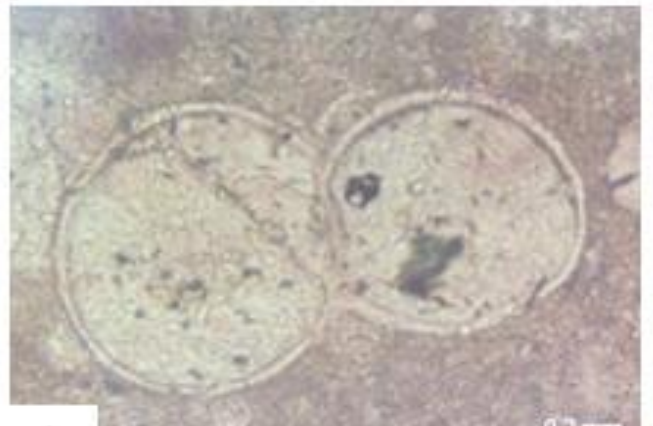

1
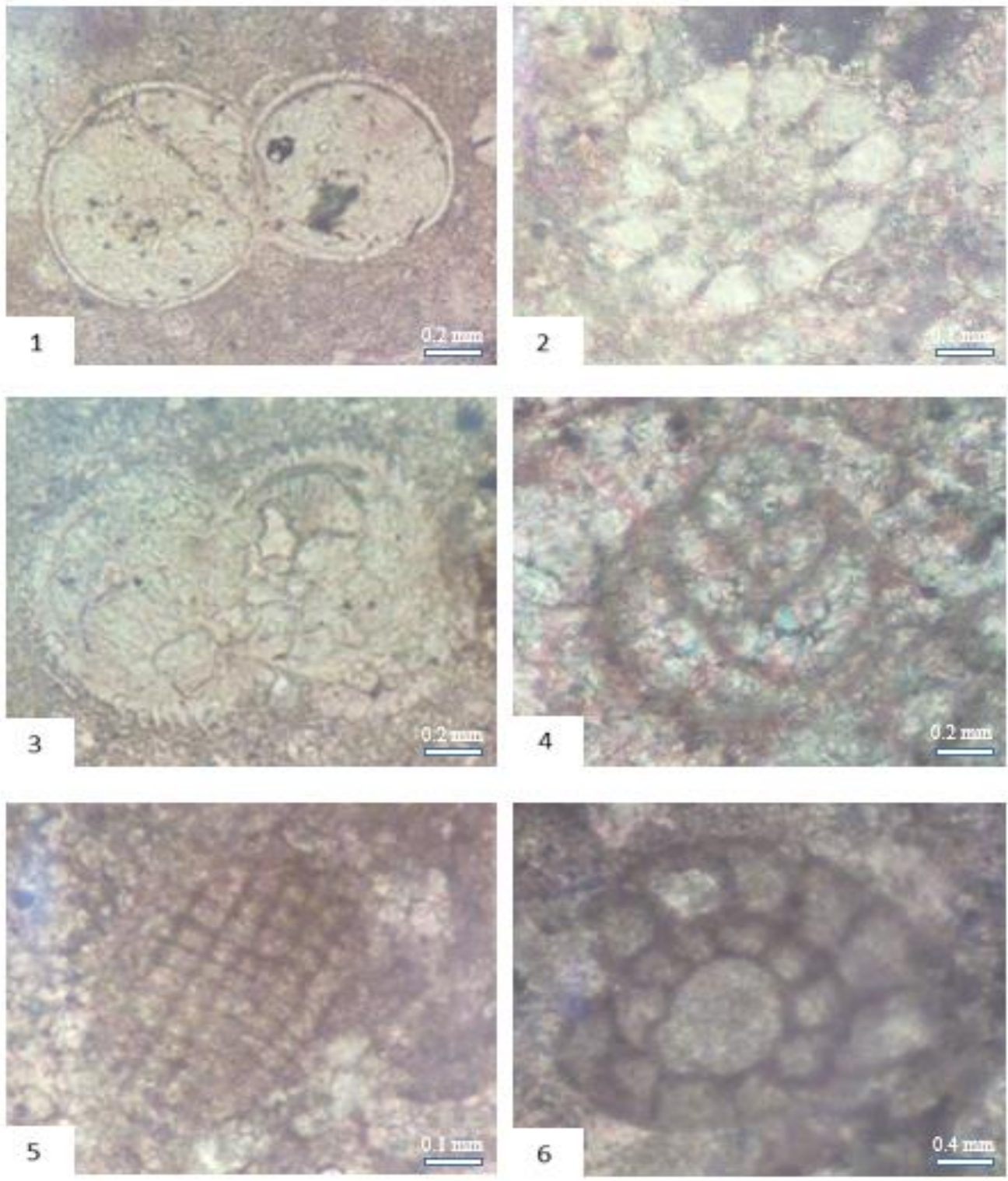

Figure 1 Bucherina sandidgei Bronnimann \& Brown, Kanny dirka section, sample no. 17, Shiranish Formation.

Figure 2 Echinoderm spine, Kanny dirka section, sample no. 9, Shiranish Formation. Figure 3 Bucherina sandidgei Bronnimann \& Brown, Kanny dirka section, sample no. 20, Shiranish Formation.

Figure 4 Eggerellina gibbosa Marie, Kanny dirka section, sample no. 5, Shiranish Formation. Figure 5 Red algae, Kanny dirka section, sample no. 1, Shiranish Formation. Figure 6 Rotalia sp., Kanny dirka section, sample no. 1, Shiranish Formation. 


\section{Plate-18}
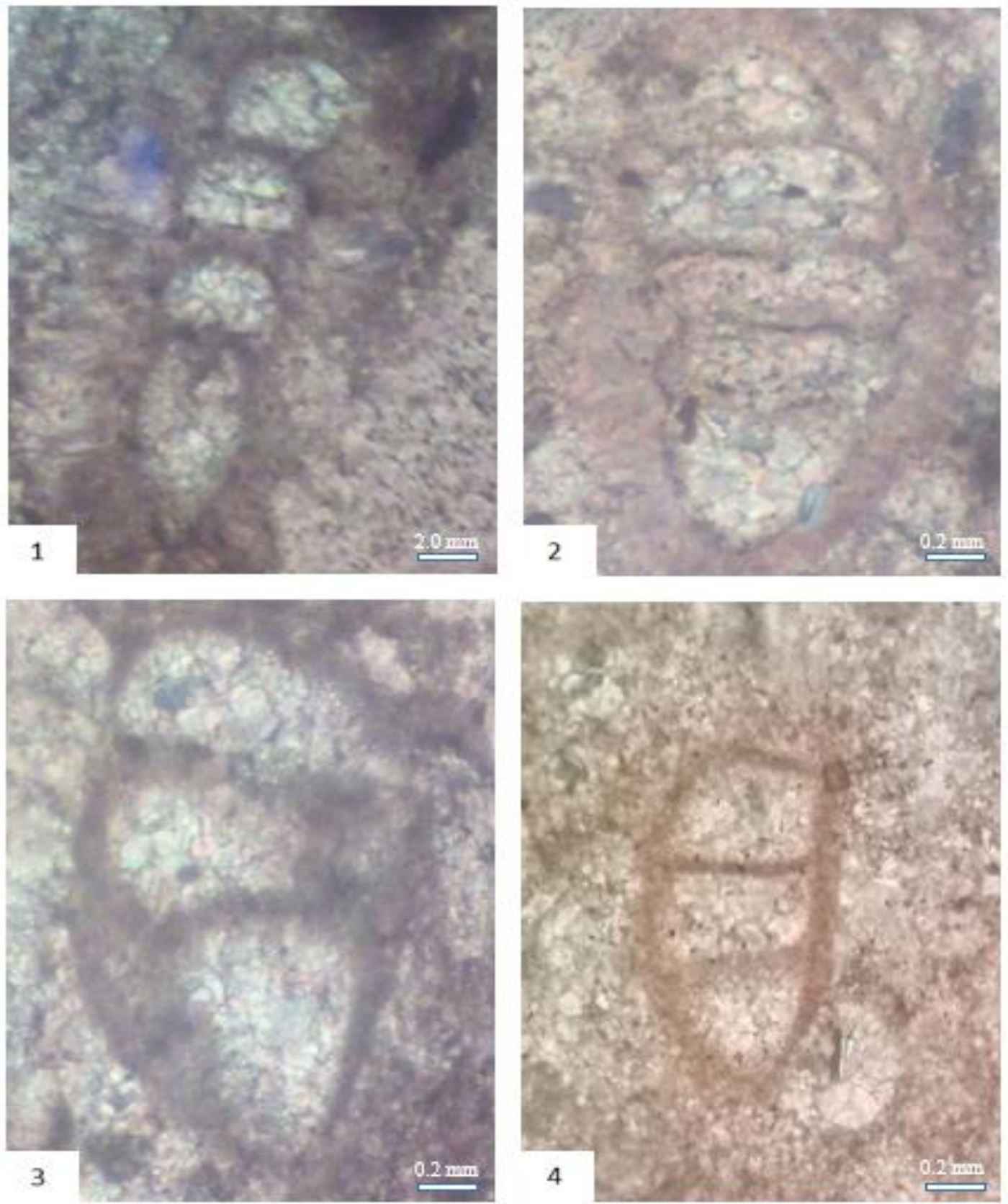

Figure 1 Nodosaria sp., Kanny dirka section, sample no. 1, Shiranish Formation.

Figure 2 Marginlinopsis anstinana (Cushman), Kanny dirka section, sample no. 1, Shiranish Formation.

Figure 3 Part of Rotalia, Kanny dirka section, sample no. 1, Shiranish Formation. Figure 4 Radiolaria sp., Kanny dirka section, sample no. 7, Shiranish Formation. 


\section{Plate-19}
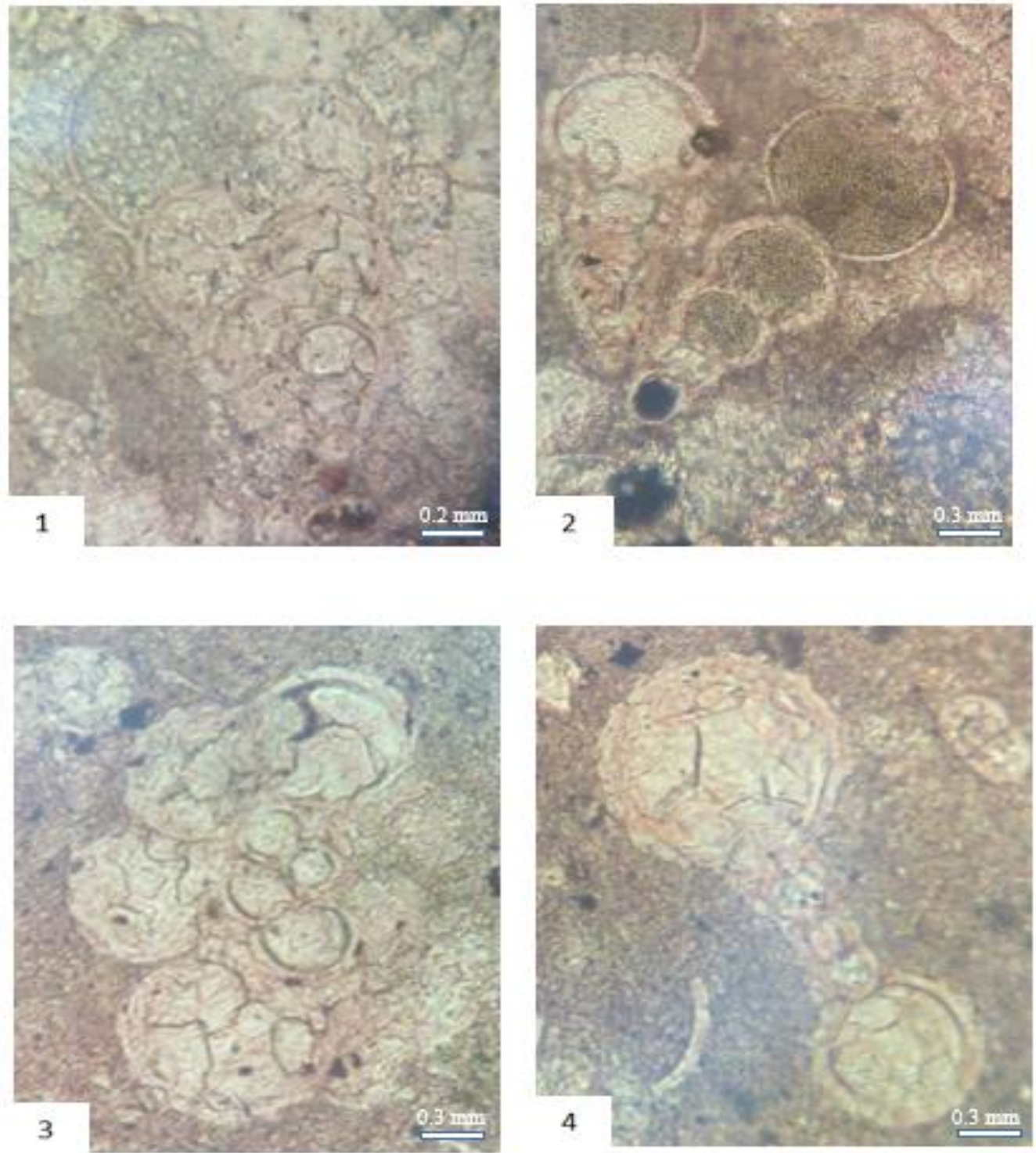

Figure 1 Heterohelix striata Eherenberg, Kanny dirka section, sample no. 13, Shiranish Formation.

Figure 2 Heterohelix sp., Kanny dirka section, sample no. 12, Shiranish Formation.

Figure 3 Globigerinelloides multispina (Lalicker), Kanny dirka section, sample no. 17, Shiranish Formation.

Figure 4 Hedbergella sp., Kanny dirka section, sample no. 18, Shiranish Formation. 


\section{Plate-20}
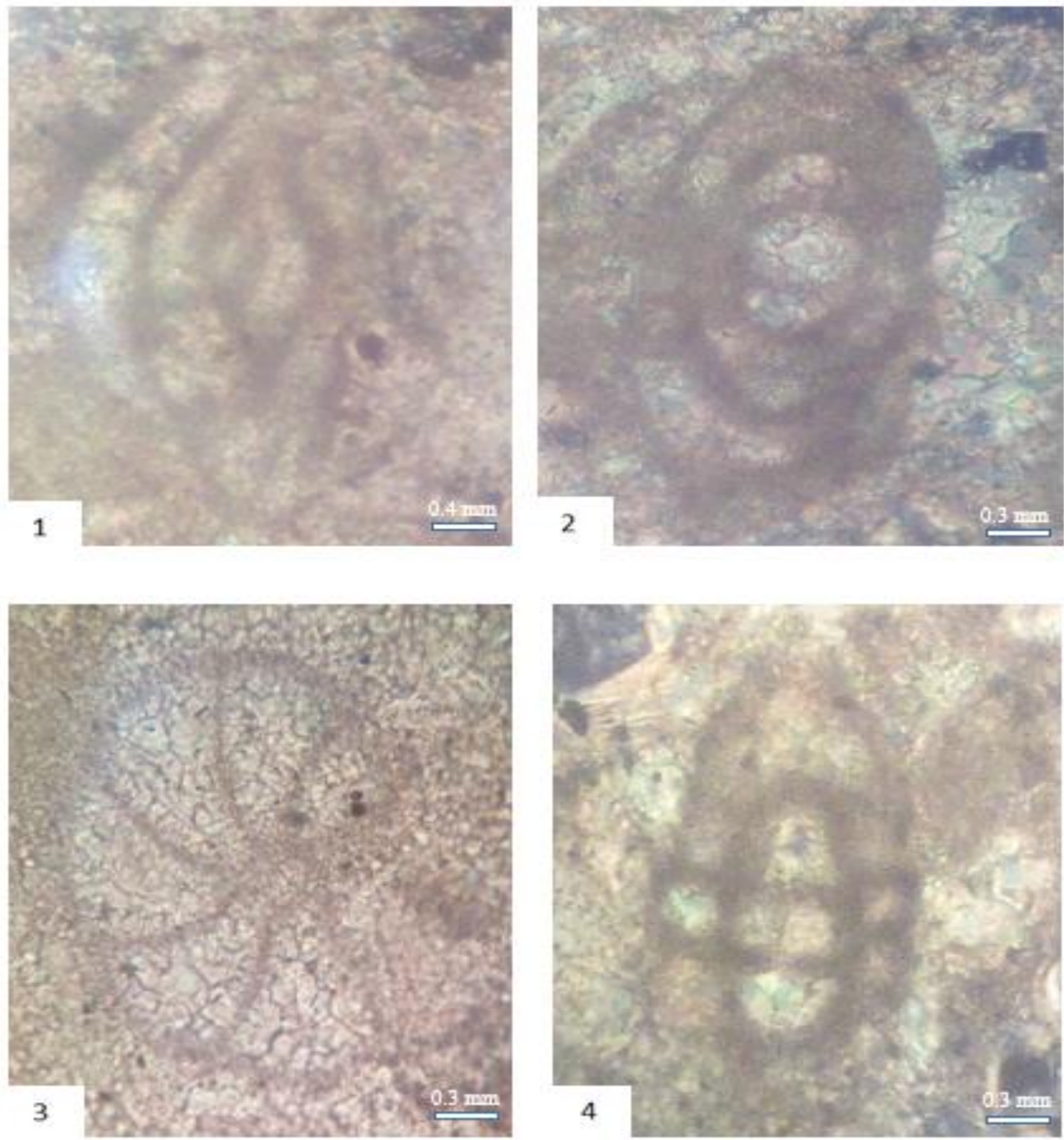

Figure 1 Miliolid sp., Kanny dirka section, sample no. 2, Shiranish Formation. Figure 2 Elphidium sp., Kanny dirka section, sample no. 8, Shiranish Formation. Figure 3 Cibicides sp., Kanny dirka section, sample no. 4, Shiranish Formation. Figure 4 Lenticulina sp., Kanny dirka section, sample no. 6, Shiranish Formation.

\section{References}

[1] Oppel, A. Die Juraformation Englands, Frankreichs und des sudwestlichen Deutschlands, nach ihren einzelnen gliedrn eingetheilt und verglichen. Von Ebner and Seubert, Stuttgart. (Originally published in three parts in Abdruck der Wurttemb. Naturw Jahreshefte 12-14; 1856, 1-438; 1857, 439 bis- 694+ map; 1856-1858, 695-857+ table).

[2] Quenstedt, F.A. Der Jura. Tubingen, H. Lauppschen. 842+ vi p., 101 pls. (published in parts: April 1856, 1-208, pls. 1-24; September 1856, 209-368, pls. 25-49; Desember 1856, 369-576, pls. 50-72; May 1857, 577-823, pls. 73-100; 1856-1858, title pages and indexes).

[3] Orbigny, A.D. Paleontology Francaise. Description Zoologique et geologique de tous les animaux mollusques et rayonnes fossils de France. 2 (Gastropoda) Victor Masson, Paris. 456 p., pls. 149236 bis, $1842-1843$. 
[4] Mojsisovics, E.V. "Das Gebirge um Hallstatt, Part 1, Die Cephalopoden der Hallstatter Kalke. Wien”, Geol. Reichsanst. Vol. 6, no. 1, pp. 1-82, 1873.

[5] Spath, L.F. Amonograph of the Ammonoidea of the Gault. Palaeont. Soc. Monogr. 787+ xix p. 72 pls, 1923-1943.

[6] Arkell, W.J., The Jurassic System in Great Britain. Oxford University press, Oxford. 681+ xii p., $41 \mathrm{pls}, 1933$.

[7] Kauffman, E.G., and Hazel, J.E. Concept and Methods of Biostratigraphy. Dowden, Hutchinson and Ross Inc., Stroudsurg, Pennsylvania, 1977.

[8] Postuma J. A. Manual of Planktonic Foraminifera. Elsevier publishing company. , 1971, p.406.

[9] Kennedy, W.J \& Klinger, H.C. Cretaceous faunas from Zululand and Natal, South Africa. The ammonite family Tetragonitidae, HYATT, 1900. - Ann. South Afr. Museum, 73/7: 149- 197, 27 Figures - Cape Town, 1977.

[10] Kennedy, W.J \& Summesberger, H. New Upper Campanian Ammonites from the Gschliefgraben near Gmunden (Ultrahelvetic, Austria). - Beitr. Paläont., vol. 24, pp. 23-39, 1999, 3 pls. - Wien.

[11] Ward, P.D. and Kennedy, W.J. "Maastrichtian Ammonites from the Biscay Region" (France, Spain). Memoir (The Paleontological Society), Journal of Palenotology 34 , vol. 67, no.5, pp. 158, 1993.

[12] Rawson, P.F., Dhondt, A.V., Hancock, J.M. and Kennedy, W.J., eds., 1996. Proceeding "Second International Sumposium on Cretaceous stagy Boundaries" Brussels 8-16 September 1995.

[13] Robaszynski, F., Gonzalez Donoso, J. M., Linares, D., Amedro, F., Caron, M., Dupuis, C., Dhondt, A.V. et Garther, S. Le Cretace Superieur de la Region de Kalaat Senan, Tunise Central, litho- Biostratigraphie Intee: Zones d Ammonites, de Foramaniniferes Planctoniques et de Nannofossils du Turonien Superieur au Maastrichtian. Bull. Centers Rech. Explor- Prod. ElfAquitaine 22, vol. 2, pp. 359-490, 2000.

[14] Kennedy, W.J., and Lunn, G. "Upper Campanian (Cretaceous) Ammonites from the Shiranish Formation, Jebel Sinjar, Northweast Iraq". Paleont, vol. 74, no. 3, pp. 464-473, 2000.

[15] Al-Badrani, O.A. "Biostratigraphy and Paleoecology of Upper Cretaceous ammonite for the lower part of Shiranish Formation NW Iraq". Unpublished M.Sc. thesis. University of Mosul. P. 104 (In Arabic), 2002.

[16] Youkhanna, A.K. "Foraminifera Marine sediments of North- East Iraq". Unpublished Ph.D. thesis, Univ. of Wales (Swan Sea), 1976.

[17] Jawi, A., \& Said, V.Y. Biostratigraphic study of shiranish - Formation in Sinjar Area, SOM. rep. ,Baghdad, 18 p, 1978.

[18] Pessagno, Jr. E. A. "Stratigraphy and Micropaleontology of the Cretaceous and Lower Tertiary of Puerto Rico". Micropaleont., vol.6, no.1, pp. 87-110, 1960.

[19] Pessagno, Jr. E.A. "The Upper Cretaceous Stratigraphy and Micropaleontology of the South Central Puerto Rico". Micropaleont., vol.8, no. 3, pp. 349-368, 1962.

[20] Pessagno, Jr. E.A. "Upper Cretaceous planktonic foraminifera from the Western Gulf coastal plain". Paleontographica Americana, vol.5, no.37, pp. 249-441, 1967, 2 tables, 63 text- figs, pls. 48-101.

[21] Olsson, R. K. "Late Cretecaous planktonic foramimifera from New Jersey and Delaware". Micropaleont. vol.10, no.2, pp.157-188, 1964.

[22] El-Naggar, Z. R. M. "Stratagraphy and planktonic foraminifear of the Upper Cretaceous Lower Tertiary successions in the Esna-Idfu Region, Nile Valley, Egypt. Brit. Mis. (Nat. Hist), Bull., Geology Supp. vol. 2, pp. 1-291, 1966, pls. 1-23, text-Figures 1-18.

[23] Dalblez, F. "The genus Globotruncana in Tunista". Micro-paleont, vol.1, no.2, pp.161-171,1955, text-figs, 1-10.

[24] Kassab, I. I. M. "The genus globotruncana Cushman from the Upper Cretaceous of Northern Iraq". Journ. Geol. Soc. Iraq, vol.12, no.1, pp. 27-127, 1980, pls. 1-26, text- figures 1-23.

[25] Bolli, H. M. "The genera praeglobotuncana, Rotalipora, Globotruna and Abathaphalus in the Upper Cretaceous of Trinidad", B.W.I., pp.51-60, pls, 12-14, tf.10. In Loeblich, A.R., et al., Studies in Foraminifera, U.S. Nat. Mus. Bull, no. 215, 323 pp. 74 pls., 30 text- figs, 1975.

[26] Subbotina, N. N. Fossll Foramimifera of the U.S.S.R., Globigerlnidae, Hantkeninidae and Globorotalildae. English trans-lation Dept. Educ and sci. Nati. Lending Library for sci. and Tach., 
Collets (publ.) Ltd., London and Wellingborough (1971) pp.1-320, pls.1-25,text-Figures 1-8, 1953.

[27] Edgell, H.S. "The genus Globotruncana in northwest Australda", Micropaleontol., vol.3, no.2, pp.101-126, 1957, pls.1-4, text-Figures 1-4 table 1.

[28] Belford, 1960. In [16] Youkhanna, A.K. "Foraminifera Marine sediments of North- East Iraq". Unpublished Ph.D. thesis, Univ. of Wales (Swan Sea), 1960.

[29] Barr, F.T. "Cretaceous biostratigrafhy and planktonic foraminifera of Libya". Micropaleont., vol.18, no.1, pp.1-46, 1972.

[30] Premolisilva, I., and Bolli, H.M. Late cretaceous to Ecoeno planktonic foraminifera and stratigraphy of Leg 15 Sites in the Caribbean Sea. Initial Reports of the Deep sea Drilling project, Vol.xv, page 499-547, 1971.

[31] Barr, F.T. "Upper cretaceous planktonic foraminfera from the Isle of Wight, England", Paleontology, vol.4, pt.4, pp.552-580, 1962, pl.69-72.

[32] Barr, F.T. "Late Cretaceous planktonic foraminifera from the Coastal area east of Susa northeastern Libya". Jour. Paleont., vol.42, no.2, pp.308-321, 1968, pls.37-40, 5 text-Figures

[33] Barr, F.T. 1927. In [16] Youkhanna, A.K. 1976. "Foraminifera Marine sediments of North- East Iraq. Unpublished Ph.D. thesis, Univ. of Wales (Swan Sea).

[34] Al-Jawary, H.A.H. "Upper Cretaceous study in selected section in Safaiya oil Field (N-W Iraq)", Unpublished M.Sc. Thesis, University of Baghdad, P.151 (In Arabic), 1989. 